\title{
FALSEDAD DOCUMENTAL COMO DELITO CONTRA EL DERECHO A LA VERDAD
}

\author{
Documental forgery as a crime against the right to truth
}

\author{
Luis Emilio Rojas A. \\ Dedicado a Joachim Vogel
}

\begin{abstract}
Resumen: La forma tradicional de abordar la cuestión del fin de protección de las normas sobre falsedad documental ha estado históricamente condicionada por una técnica legislativa que mezcla en una misma norma la protección de la autenticidad y de la verdad del documento público. Esta confusión ha favorecido la acogida de la tesis de la fe pública y, modernamente, ha impedido a la doctrina nacional y española darse cuenta que la teoría de las funciones, desarrollada en el ámbito de la doctrina alemana, se invoca para esclarecer el fundamento de la norma del Código penal alemán que castiga el injusto básico del delito de falsedad documental -\$ 267 I Strafgesetz̧buch. Luego de poner orden en esta discusión y revisar críticamente esta teoría, se descubre que, en el umbral del siglo XXI, se asiste a un auténtico regreso del derecho a la verdad para la justificación racional de las normas sobre falsedad documental. La presente investigación se inscribe en esta tendencia teórica, a partir de la que, en la segunda parte del trabajo se esclarece la estructura de los delitos de falsedad documental y de los delitos de uso malicioso de documento falso. Esta aclaración sirve de base para, finalmente, proponer una delimitación del iter criminis de ambos delitos, según la que estos se desarrollan y ejecutan en un iter criminis sin solución de continuidad.
\end{abstract}

Palabras clave: Autenticidad - verdad - falsedad documental - uso de documento falso.

Abstract: The traditional way of addressing the issue of the protection's aim of the norms concerning documental forgery has been historically conditioned by a legislative technique that mixes up, in the same norm, the protection of authenticity and the truth of the public document. This confusion has favoured the publica fides thesis and, in the twentieth century, has prevented national and spanish doctrine of realizing that the theory of functions, developed by german scholars, is the one invoked to clarify the foundation of the German Criminal Code rule that punishes the basic criminal action of forgery -\$267 I Strafgesetzbuch. After bringing order in this debate and critically reviewing this theory, it comes up that, on the threshold of the twenty-first century, we are witnessing a real return of the right to truth in the rational justification of the rules concerning document falsification. The current study adopts this theoretical approach according to which the second part of this work sheds light into the structure of the crimes of documental forgery, malicious use of false document. Finally, this clarification provides the grounds for proposing an iter criminis's delimitation of both kind of crimes according to which they are developed and commited in a continuing process.

* LL.M. y Dr. iur. Albert-Ludwigs-UniversitätFreiburg - Profesor de Derecho penal en la Universidad Alberto Hurtado: lurojas@uahurtado.cl; el presente trabajo es un producto ulterior del proyecto Fondecyt N. 1110512: "Falsedades documentales: entre autenticidad y verdad. Hacia una revisión del sistema de delitos de los artículos 193 a 198 del Código penal", del que el autor fue investigador responsable.

Este artículo fue recibido el 19 de enero de 2015, siendo aprobada su publicación el 31 de mayo de 2015. 
Rojas - Falsedad documental como delito contra el derecho a la verdad

Key words: Authenticity - truth - document's forgery - use of false document.

\section{Introducción y tesis}

A continuación se aborda la discusión sobre el fin de protección de las normas de los artículos 193 a 198 del Código penal (en adelante, CP), partiendo de la premisa que estas normas configuran un sistema. Su legitimación surge de la protección que ellas brindan a dos intereses diversos, pero relacionados entre sí: el interés en la protección de la autenticidad y el interés en la protección de la verdad. Luego, se propone una tesis explicativa de los tipos de falsedad contemplados en los artículos 193, 194 y 197, según la cual estos comparten una misma estructura: se encuentran configurados como delitos de peligro. A renglón seguido, los tipos de uso malicioso de documento falso previstos en los artículos 196 y 198CP comparten también una misma estructura, pero se encuentran configurados como delitos de lesión.

Estos planteamientos teóricos se basan en una reconstrucción dogmática del sistema de normas referido. Las siguientes premisas subyacen a esta propuesta dogmática:

1a "En el principio es el verbo", la conducta prohibida se encuentra descrita ya en el encabezado del Art. 193 CP con la frase "cometer falsedad".

$2^{a}$ Los tipos de los artículos 193, 194 y 197 comparten la misma forma de descripción de la conducta prohibida.

$3^{\text {a }}$ Subyace a los tipos de los artículos 193, 194 y 197 la misma norma prohibitiva que reza: "está prohibido cometer falsedad en un documento, público o privado".

$4^{a}$ Los numerales 1 a 8 del Art. 193 describen solamente modalidades de comisión de la conducta prohibida.

$5^{\text {a }}$ La distinción epistemológica entre autenticidad como forma de verdad en el sentido del Art. 17 inciso $2^{\circ}$ del Código civil y verdad como correspondencia entre narración y hecho (Art. 193 N. 4 CP).

6 ${ }^{a}$ Los tipos de los artículos 193 y 194 abarcan un doble injusto: la creación de un documento público falso en el sentido de inauténtico y, también, la creación de un documento público existente, pero falso porque su declaración no se corresponde con un hecho jurídicamente relevante (Art. 193 N. 4 CP).

$7^{\mathrm{a}}$ La protección de la verdad, empero, se restringe al documento testimonial público sobre un hecho jurídicamente relevante.

$8^{a}$ El tipo del Art. 197 CP se agota en el injusto básico del delito de falsedad documental, esto es, la creación de un documento privado o mercantil falso en el sentido de inauténtico.

Sobre la base de estas premisas, es posible abordar la pregunta por el fin de protección de las normas (2.), luego la cuestión de la estructura de los tipos de falsedad y de uso 
malicioso de documento falso (3.), para finalmente extraer las consecuencias de este planteamiento para la delimitación del iter criminis en ambos delitos (4.).

\section{El fin de protección de las normas de los artículos 193 a 198 CP}

\section{a) Distinción previa histórica y metodológica}

La discusión dogmática en torno al fin de protección de estas normas se encuentra plagada de confusiones. Esta discusión equívoca y confusa tiene su origen, por una parte, en la defectuosa técnica legislativa adoptada en el Código penal de 1874, puesto que el legislador nacional del siglo XIX mezcló en la misma norma del Art. 193 la protección de intereses diversos que resultan vulnerados al cometer falsedad en un documento público. Según la clase de falsedad cometida en un documento público, puede resultar un atentado a la autenticidad del mismo o la vulneración del interés en la protección de su verdad. Ambos intereses de protección quedan abarcados por el texto de la norma. La doctrina dominante no los reconoce como tales, porque el título IV del Libro II, en cuyo párrafo $4^{\circ}$ se inserta esta norma, se refiere expresamente a los "crímenes y simples delitos contra la fe pública", concepto oscuro que impide vislumbrar los intereses jurídicamente protegidos por la norma del Art. 193 CP. ${ }^{1}$ Por otra parte, el Código penal de 1874 sigue la sistemática del Código penal español de 1848/50, el que a su vez, mediado por el Código penal español de 1822, sigue la sistemática del Code Pénal de 1810. Lo característico de esta sistemática radica en que antepone, en el grupo de los delitos de falsedad documental, el tipo referido a la falsedad cometida por un empleado público en un documento público (Art. $193 \mathrm{CP}$ ), para seguir con aquella norma que criminaliza la realizada por un particular en el mismo documento (Art. 194 $\mathrm{CP}$ ) y concluir con el tipo relativo a la falsedad cometida en un documento privado (Art. 197 CP). Esta sistemática se mantiene en el Código penal español de 1995 en sus artículos 390, 392 y 395, respectivamente. ${ }^{2}$

En cambio, en la sistemática del Código penal alemán (en adelante, StGB), ya desde su versión original de 1871, se antepone el tipo que describe el injusto básico del delito de falsedad documental en el $\$ 267$, para luego contemplar el tipo de falsa documentación cometida por un particular en un documento o registro público en el $\$ 271 \mathrm{y}$, finalmente, relegar el tipo de falsedad en el cargo cometida por un empleado público al \348 entre los delitos funcionarios ("Straftatenim $\left.A m t^{\prime}\right)$. Esta diferente técnica legislativa y sistemática, que puede constatarse entre ambas formas de codificación de este grupo de delitos, ha distorsionado la discusión sobre el fin de protección de las normas en el ámbito de la doctrina española y nacional. La discusión que ya se plantea en el siglo XIX entre la tesis de la fe pública y el derecho a la verdad en la doctrina alemana y que, posteriormente durante el siglo XX, se replantea en los términos de la teoría de las funciones, gira en torno al problema de legitimación de la norma cuyo tipo describe el injusto básico

\footnotetext{
${ }^{1}$ Rojas (2014 b), pp. 481 y ss.
}

2 ROJAS (2012), pp. 563 y ss. 
Rojas - Falsedad documental como delito contra el derecho a la verdad

del delito de falsedad documental, esto es, el $\$ 267$ StGB. La doctrina española y la nacional intervienen en esta discusión para esclarecer el fundamento de la norma que, en la Codificación penal española y chilena, describe la falsedad cometida por un empleado público en un documento público, vale decir, en el Código penal español de 1995 el Art. 390 y en el Código penal chileno aún vigente el Art. 193. Esta forma de abordar la cuestión por parte de la doctrina española y la nacional, en términos coloquiales, coloca de cabeza la discusión de la dogmática alemana.

Lo anterior explica que la tesis de la fe pública haya gozado de un éxito comparativamente mayor en la doctrina de raigambre latina que en la doctrina alemana. También explica que su versión moderna en la tesis de la función probatoria del documento goce de un éxito mayor frente a su contrincante teoría de la función de garantía. Puesto que se tiende a asociar el valor probatorio al documento público, mas no en la misma medida al documento privado. ${ }^{3}$

El método que se propone para abordar esta discusión consiste básicamente en suspender, por un momento, la pregunta por el fin de protección de las normas, también conocida como pregunta por el "bien jurídico protegido", si se opta por usar el lenguaje de la teoría del bien jurídico. Y formular, en su lugar, la pregunta por el injusto de la conducta descrita en los tipos de los artículos 193, 194 y 197 CP. ${ }^{4}$ Cierto, este método es en buena medida positivista e incluso podría tildarse de exegético. Pero aquí pareciera que el dictum de origen bíblico, según el que en el principio es el verbo, puede aportar una gran dosis de claridad a la discusión. Conforme a este método, en vez de salir en busca de bienes detrás de normas, como procede la teoría del bien jurídico, se antepone la pregunta por el injusto de la conducta descrita en los tipos de los artículos 193, 194 y 197 CP. En esta aproximación resulta inevitable aquello que precisamente se evita en la propuesta metodológica presa de la teoría del bien jurídico, esto es, intentar responder previamente a la pregunta por el significado de la frase "cometer falsedad en un documento", público o privado. Solamente en la medida en que se intenta responder a esta pregunta es posible esclarecer el injusto propio de los delitos de falsedad documental. ${ }^{5}$ Luego, en una operación de reformulación contradictoria del injusto propio de estos delitos es posible determinar lo justo, esto es, los intereses jurídicamente protegidos por las normas citadas.

\footnotetext{
3 Cfr. COUSIÑo (1944), pp. 13 y ss.; Grisolía (1956), p. 96: "Precisamente, el bien jurídico protegido por los delitos de falsedad documental es el valor probatorio del documento, su integridad y pureza que dependen no solo de su existencia jurídica como tal y de su genuinidad, sino también de su veracidad en los extremos en que la ley ofrece la certeza de su verdad o, para usar terminología más corriente, en aquellas partes en que el documento está llamado a hacer plena fe, de suerte que la no veracidad, o sea, la mentira con necesaria trascendencia jurídica sobre los extremos referidos, lesiona el bien tutelado y produce el perjuicio que va ínsito en estas figuras"; como puede observarse en esta cita, el bien jurídico "valor probatorio" abarca tanto la "genuinidad" o autenticidad como la "veracidad" del documento, esto es, articula en un concepto los intereses de protección que la norma del Art. 193 CP mezcla.

${ }^{4}$ ROJAS (2014 a), pp. 525 y ss.

5 Ibid., pp. 545 y ss., y ROJAS (2014 b), pp. 512 y ss.
} 
Esta aproximación metodológica ha permitido esclarecer que las normas de los artículos 193 y 194 CP abarcan un doble injusto. Tanto el injusto básico del delito que surge de la creación de un documento público falso en el sentido de inauténtico como aquel injusto del delito que provoca la creación de un documento público existente, pero cuya narración no se corresponde con un hecho externo jurídicamente relevante (Art. 193 N. 4 CP). Dicho en términos positivos, estas normas protegen tanto la autenticidad como la verdad del documento público. En cambio, la norma del Art. 197 CP abarca solamente el injusto básico del delito de falsedad documental, esto es, la creación de un documento privado o mercantil falso en el sentido de inauténtico -inexistente- ${ }^{6}$ Por tanto, esta última norma protege solamente la autenticidad del documento privado o mercantil. ${ }^{7}$

La pregunta que ahora se formula atañe al fundamento de punibilidad del delito de falsedad documental. ¿Por qué se castiga la creación de un documento público o privado falso en el sentido de inauténtico? Formulado en términos positivos ¿por qué se protege la autenticidad de un documento público o privado? Esta pregunta debe distinguirse de aquella que concierne al fundamento de punibilidad del injusto que proviene de la creación de un documento público falso en el sentido de que su declaración (testimonial) no se corresponde con un hecho externo jurídicamente relevante.

Dicho en otros términos, la pregunta por el fundamento de la protección ala autenticidad del documento debe distinguirse del problema de legitimación que plantea una norma que protege (también) la verdad del documento público y, en consecuencia, ambas cuestiones deben abordarse por separado. En términos coloquiales, a continuación se intenta poner nuevamente de pie la discusión de la doctrina alemana sobre el fin de protección de la norma sobre falsedad documental.

\section{b) Legitimación de la norma de protección a la autenticidad del documento}

\section{i) Discusión histórica}

De acuerdo con este recorrido trazado metodológicamente, en primer lugar, cabe abordar la cuestión de la legitimación de una norma que protege la autenticidad del documento, público o privado. Históricamente, en el siglo XIX, la discusión se centró en la disputa entre el derecho a la verdad y la fe pública como propuestas de justificación de la norma. ${ }^{8}$ A partir del rechazo del derecho a la verdad como objeto protegido por la norma y su degradación a un medio de ataque para la

\footnotetext{
${ }^{6}$ RojAs (2014 a), pp. 545 y ss.

7 Pues, como sostiene recientemente BACIGALupo (2007), p. 101: "la 'verdad' de los documentos privados es lo que garantizan, es decir, se reduce a su autenticidad”' (destacado original).

8 Véase ROJAS (2012), pp. 568 y ss., y ROJAS (2013), pp. 940 y ss.
} 
lesión de otro derecho, la tesis de la fe pública se volvió dominante. ${ }^{9}$ En esta dirección, Hälschner rechaza el derecho a la verdad y sostiene que lo consustancial al tipo de falsedad no es la lesión de algún interés individual, puesto que este delito se dirige contra la sociedad, lesiona "la fides publica, la buena fe, como presupuesto necesario del tráfico jurídico, un bien social imprescindible a proteger jurídicopenalmente". ${ }^{10}$ También Adolf Merkel sostuvo inicialmente la tesis de la fe pública, pero posteriormente se inclinó por una justificación basada en la protección de la "fuerza probatoria de ciertas formas de autentificación" (Beglaubigungsformen). ${ }^{11} \mathrm{La}$ tesis de la fe pública puede rechazarse, entre otras razones, porque es incapaz de ofrecer una justificación a la protección de la autenticidad del documento privado. ${ }^{12}$ $\mathrm{Al}$ concluir su acérrima crítica a la tesis de la fe pública, Binding sostiene que esta no es más que una mutación del antiguo derecho a la verdad, contra el cual aquella pretendía oponerse: "tampoco mediante su transformación en la fe pública ha podido sobrevivir el antiguo derecho a la verdad, ¡Que en paz descanse!”. ${ }^{13}$

En su lugar, postula que el bien jurídico es "la pureza de la producción de pruebas dependiente de la autenticidad y veracidad de los medios de prueba". ${ }^{14}$ Sin embargo, esta tesis la sostiene Binding en el marco de la introducción a los delitos probatorios en general, incluido el perjurio y el falso testimonio. Es en este contexto donde distingue tres formas de ataque a este bien jurídico. En primer lugar, probar lo verdadero o no verdadero con medios de prueba inauténticos. En segundo lugar, probar lo no verdadero -Unwabres- con medios de prueba auténticos. Y, en tercer lugar, impedir la prueba mediante la destrucción de medios de prueba auténticos. La protección de este bien jurídico se logra mediante tres prohibiciones. La prohibición de probar lo verdadero o no verdadero con medios de prueba inauténticos, que dota de contenido a la norma sobre falsedad documental (1.). La prohibición de probar lo no verdadero con medios de prueba auténticos, que es común a las normas sobre perjurio, falso testimonio y falsa documentación pública (2.).La prohibición de impedir la prueba mediante la destrucción de medios de prueba auténticos, que subyace a diferentes normas sobre signos probatorios y de autentificación -Beweiszeichen(3.)- ${ }^{15}$ Cada una de estas prohibiciones fue reformulada por Paul Merkel en los términos de un derecho correlativo. Así, a la prohibición de probar con documentos inauténticos corresponde "el derecho de cada uno a la autenticidad de los documentos usados en contra para la prueba" (1.). La prohibición de probar lo no verdadero con documentos auténticos es correlativa de lege lata al "derecho de cada uno a la verdad del contenido de documentos públicos con contenido jurídico relevante y de certificados de salud"

\footnotetext{
${ }^{9}$ Cfr. JakoBs (2000), p. 1 y ss.

${ }^{10}$ HÄLSCHNER (1887), \} 1 5 3 \text { p. 514, y HÄLSCHNER (1868), \55 p. } 3 4 7 \text { y s., rechazo a la tesis del } derecho a la verdad en el comentario previo al tipo de estafa.

${ }^{11}$ Merkel, Adolf(1867), p. 16, y MERKEL, Adolf (1889), @ 140, p. 358.

${ }^{12}$ Cfr. Binding (1904), p. 126.

${ }^{13}$ Ibid., p. 127 y s.

${ }^{14}$ Ibid., p. 115.

${ }^{15}$ Ibid., p. 119.
} 
(2.). A la prohibición de impedir o frustrar mediante daño u ocultación de documentos corresponde "el derecho al ejercicio libre de la facultad de uso de documentos" (3.). Paul Merkel sintetiza el bien jurídico que subyace a todas estas prohibiciones y derechos en los siguientes términos: "seguridad de la prueba judicial y extrajudicial con documentos". ${ }^{16}$

Esta reformulación de las prohibiciones en derechos subjetivos individuales, sin embargo, fue tildada por Binding de insostenible: "En especial, me parece que un derecho 'de cada uno a la verdad del contenido de documentos públicos con contenido jurídico relevante y de certificados de salud' es un derecho aberrante" ${ }^{17}$ Este rechazo de Binding a la propuesta de Paul Merkel se explica fácilmente, ya que su aceptación implicaba resucitar el antiguo derecho a la verdad, cuya muerte había declarado de modo tajante y definitivo.

Modernamente, ya en la segunda mitad del siglo XX, la discusión sobre el fundamento de la protección brindada a la autenticidad del documento se ha replanteado en los términos de la teoría de las funciones. ${ }^{18}$ Así planteada, en plural, esta teoría sostendría que el fundamento de legitimación de la norma radica en la protección de las funciones que el documento cumple en el tráfico jurídico. ${ }^{19}$ Estas funciones serían tres: función de perpetuación (1.), función probatoria (2.) y función de garantía (3.).

\section{ii) Teoría de las funciones: perpetuación}

Respecto de la función de perpetuación (1.), seguir esta teoría implica sostener que la norma que prohíbe la falsedad documental encuentra su justificación en la protección de esta función. ${ }^{20}$ En efecto, el documento presta un rendimiento que la

\footnotetext{
${ }^{16}$ MERKEL, Paul (1902), p. 203 y s.

${ }^{17}$ BINDING (1904), p. 119 nota 3: "monströs” (destacado agregado).

${ }^{18}$ Es difícil identificar un momento fundacional de esta teoría. En la primera mitad del siglo XX se proponen distintas reformulaciones de las tesis ya sostenidas en el siglo XIX. En este sentido, VON LISZT (1908), \160, p. 520, "el legislador protege el documento no por sí mismo, sino que en protección de los distintos bienes jurídicos para los cuales el documento puede tener relevancia en el tráfico jurídico"; similar, en Italia, ANTILOSEI (1951), pp. 632 y ss., según el cual se trata de la protección de aquel interés particular salvaguardado por la genuinidad y veracidad del medio de prueba y de la fe pública en el sentido de confianza y seguridad del tráfico jurídico; FrANK (1908), \267, p. 448, "los documentos gozan de especial protección jurídico-penal en atención a su significado fundamental para la vida jurídica". Quizás Frank puede considerarse un precursor de esta teoría. Hasta donde se alcanza a vislumbrar, al menos en la dogmática alemana de la parte especial, no se sostiene una teoría de las funciones así en plural, sino que más bien se toma postura respecto de una función que sería determinante del fundamento de protección.

19 Así se sostiene en la doctrina española por varios autores (GARCíA CANTIZANO, 1997, pp. 40 y ss.; Villacampa Estiarte, 1999, pp. 437 y ss.); crítico Boldova Pasamar (2000), pp. 153 y ss.; también BACIGALUPO (2007), pp. 100 y ss.

${ }^{20}$ Cfr. SAMSON (1968), p. 118 y s., sin embargo, este autor sostiene que mediante la amenaza penal se garantiza la confianza general en la autenticidad de los documentos, sin la cual estos no podrían cumplir cabalmente su función de perpetuación ("si uno tuviese que contar en el tráfico jurídico
} 
Rojas - Falsedad documental como delito contra el derecho a la verdad

declaración oral no puede cumplir, cual es que al fijarse una declaración de voluntad -documento dispositivo- o de conocimiento-documento testimonial-, esta se vuelve independiente de la voluntad de los sujetos que intervienen en su otorgamiento y permite ser reconocida en el tráfico jurídico como emitida por la persona que aparece como su autor, sin necesidad de recurrir nuevamente a los intervinientes originales. Este rendimiento del documento trae aparejada una debilidad, que comparativamente no se presenta en la declaración oral. ${ }^{21}$ Con esta última, es posible sin más la imputación de la declaración a su autor, mientras se encuentre presente, lo que dificulta su falsificación. En cambio, al fijarse este nexo en un documento, este se expone a que la imputación de la declaración a su autor se vea alterada o sea producida incorrectamente. ${ }^{22}$ La norma que prohíbe la falsedad documental se dirige precisamente a evitar esta conducta.

Pero, de este modo, esta teoría ofrece solamente una explicación de la existencia de esta norma de prohibición. Sise recurre a ella para obtener un fundamento de la norma, se vuelve tautológica: se prohíbe la falsedad documental porque el documento se expone a su falsificación. Podría rescatarse esta teoría, si su explicación se reformulase en términos positivos: la norma de prohibición de la falsedad documental se legitima por la protección del documento. Ya que, en rigor, el documento se diferencia de la declaración oral precisamente en su fijación, no en su contenido, que puede ser exactamente el mismo. Ergo, es impreciso sostener que el documento cumple una función de perpetuación. No es que el documento cumpla esta función, es fijación en signos de una declaración de voluntad o de conocimiento. ${ }^{23}$ Dicha reformulación, sin embargo, se expondría a la objeción, tan usual desde la teoría del bien jurídico, de confundir el objeto de la conducta típica con el objeto jurídico protegido por la norma. Esta objeción podría todavíasalvarse al sostener que la norma protege la institución del documento. ${ }^{24}$ No obstante, aún en esta versión quedaría pendiente la respuesta a la pregunta de si esta institución es valiosa por sí misma o si existe un interés en su protección, cuyo titular es la sociedad en su conjunto o una persona individual.

con que los documentos son inauténticos, el instrumento en sí beneficioso de la declaración perpetuada se volvería inútil'), por ende, la confianza incrementada en la autenticidad del documento es consecuencia de la amenaza penal; pero, si esto es así, entonces la confianza en la autenticidad no puede fungir como bien jurídico, pues se crea o refuerza mediante la misma norma que castiga la falsedad documental; véase la crítica de JAKOBS (2000), p. 20 y s.

${ }^{21}$ Cfr. LuHMANN (1993), p. 254 y s., de donde reducción y producción de complejidad.

22 SAMSON (1968), p. 118; en este sentido, RHEINECK (1979), p. 125 y s.

${ }^{23}$ Cfr. Rojas (2014 b), p. 541.

${ }^{24}$ Así lo admite indirectamente SAMSON (1968), p. 119: "la pena impuesta por la falsedad no tiene un carácter exclusivamente represivo, sino que enfrenta al ataque realizado a la institución de los documentos. Tal agresión pone en peligro la confianza general en la autenticidad de los documentos y así su aptitud funcional", y era una consecuencia lógica de su planteamiento, que le ahorraba la tortuosa construcción de una confianza en la autenticidad generada por una norma penal. 


\section{iii) Tesis de la función probatoria: crítica}

En cuanto a la función probatoria (2.), esta tesis se encuentra indisolublemente ligada al nombre de Karl Binding. Aun cuando este no la sostuviera en esos términos, su postura sobre el bien jurídico atacado en estos delitos revela que el fundamento último de legitimación de las normas radica en la producción correcta de pruebas en el proceso. La pureza de la producción de pruebas dependiente de la autenticidad y la veracidad de los medios de prueba es el bien jurídico atacado por estos delitos, sostiene Binding (vid. Supra2.b.i). Ergo, la autenticidad de los medios de prueba se protege no por sí misma, sino porque de ella depende la correcta producción de pruebas. Esta tesis se refrenda al concretar la primera prohibición, que subyace a la norma sobre falsedad documental $\int 267$ StGB, la cual reza: está prohibido probar lo verdadero o no verdadero con medios de prueba inauténticos. Aunque Binding no lo aclare, se encuentra implícito en su planteamiento que el ámbito de la prohibición de probar con medios de prueba inauténticos no se reduce al proceso. Reconoce un uso extraprocesal del documento. Pero el derecho probatorio determina qué es documento y no solamente para el proceso civil, sino que para todo suceso jurídico y para toda la vida jurídica fuera del proceso. ${ }^{25} \mathrm{El}$ tráfico, sostiene, es impotente para transformar en documento aquello que no lo es, pero todopoderoso para producir prueba como quiera, con medios de prueba jurídicamente reconocidos o de otra manera, quizás mediante documentos falsos, cuya inautenticidad sea reconocible a millas de distancia o por la declaración de una persona prestada con o sin juramento. ${ }^{26}$ Agrega que donde la oralidad termina, empiezan los documentos a cumplir nuevamente su función probatoria, principalmente en el tráfico y especialmente en los estadios de tránsito de la vida jurídica extraprocesal a la procesal. Afirma que nadie puede trasladar los principios que impiden el uso de documentos en el proceso oral a los sucesos extraprocesales de la vida jurídica que no se encuentran sometidos al principio de oralidad. ${ }^{27}$ Es decir, según Binding el documento cumple una función probatoria tanto en la vida jurídica extraprocesal como en la procesal, con la diferencia que solamente en esta última aquella se encuentra sometida estrictamente a las reglas y principios del derecho probatorio.

Frente a la pregunta por el alcance de la función probatoria, Binding recurre nuevamente al derecho probatorio, que determina el valor probatorio del documento. Este deriva no de su forma escrita -salvo excepciones legales, la palabra escrita no prueba más que la oral-, sino que proviene de la circunstancia de que:

“(...) una persona determinada responde por la verdad de la declaración documentaria. Presupuesta la autenticidad y la integridad, el valor probatorio del documento es fundamentalmente idéntico con la credibilidad de su otorgante. Este pretende volverse garante de la verdad

\footnotetext{
${ }^{25}$ BINDING (1904), p. 193.

${ }^{26}$ Ibid., p. 194 y s.

${ }^{27}$ Ibid., p. 195.
} 
Rojas - Falsedad documental como delito contra el derecho a la verdad

de su contenido mediante el otorgamiento del documento" (Binding, 1904, p. 195 y s.).”

Este pasaje clave en la obra de Binding es equívoco, porque parece usar la palabra verdad en dos sentidos diferentes. Cuando aclara que el valor probatorio del documento no deriva de su forma escrita, porque esta no prueba más que la palabra oral, sino de que una persona responde por la "verdad de la declaración documentaria", parece tratarse de la verdad sobre la existencia de una declaración emitida por la persona de su otorgante. A renglón seguido, señala que presupuesta la autenticidad del documento, su valor probatorio es básicamente idéntico a la credibilidad de su otorgante y que este se vuelve garante de la "verdad de su contenido" mediante el otorgamiento del documento, parece referirse a la verdad sobre la ocurrencia de un hecho controvertido distinto de la emisión de la declaración. No obstante, esta interpretación del pasaje citado contradice el alcance de la prohibición de "probar lo verdadero o no verdadero con documentos inauténticos", según la cual lo determinante del injusto es el uso de un medio de prueba inauténtico, siendo indiferente si su contenido es verdadero o no verdadero. En otros pasajes dedicados a los elementos constitutivos del documento, Binding precisa el alcance del valor probatorio. Aclara que el documento no prueba inmediatamente otra cosa que su contenido "y este es siempre la declaración emitida por una persona determinada". ${ }^{28}$ Luego, se refiere a la "seriedad" (Ernstlichkeit) como elemento básico del documento auténtico: "su otorgante debe realmente pretender mediante este declarar una voluntad jurídicamente relevante o fungir como garante de verdad por un hecho verdadero o no verdadero". ${ }^{29}$ Concluye: documento es "un escrito mediante el cual el otorgante responde por la verdad de un hecho jurídicamente relevante contenido, esto es, manifestado en él". ${ }^{30}$ Pero, si Binding es consistente, este hecho, por cuya verdad el otorgante de un documento responde como garante, se acota a la existencia de una declaración jurídicamente relevante. Esta limitación del valor probatorio del documento no obsta a que, mediatamente, su autenticidad pueda ser relevante para la prueba de un hecho controvertido en un proceso. ${ }^{31}$

En este último sentido, Lampe distingue entre el valor probatorio del documento y la fuerza probatoria material del mismo. El valor probatorio del documento se basa en la declaración de pensamiento corporeizada en este. Esta

\footnotetext{
${ }^{28}$ BINDING (1904), p. 204 (destacado agregado).

${ }^{29}$ Ibid., p. 207; este pasaje suena paradójico, ¿cómo podría volverse una persona garante por la verdad de un hecho no verdadero? La paradoja se disuelve, si la verdad, de la que se es garante, se reduce a aquella sobre la existencia de una declaración, cuyo contenido puede radicar en una "declaración de voluntad jurídicamente relevante" o en una declaración sobre un hecho que, a su turno, puede ser verdadero o no verdadero.

${ }^{30}$ Ibid., p. 208.

31 MALINVERNI (1958), pp. 234 y ss., 256 y s., critica a Binding y sostiene que no existe un interés en la prueba que no sea para obtener un derecho, vale decir, la verdad de la prueba es un medio que permite la comprobación judicial o extrajudicial del derecho; la tesis de Malinverni se adelanta a la que posteriormente sostendría Jakobs, vid. infra 2.b.v.
} 
declaración presupone un creador que se deriva del documento. Aclara que esto vale para el proceso y para el tráfico extraprocesal, donde el valor probatorio del documento se determina en lo esencial conforme a las mismas reglas que rigen en el proceso. ${ }^{32}$ Con la autenticidad del documento se prueba que el otorgante ha emitido la declaración contenida en él. La fuerza probatoria material del documento respecto del hecho objeto de prueba depende de la clase de documento de que se trate, esto es, si es dispositivo o testimonial y si es público o privado, todo lo que se encuentra también determinado por las reglas del proceso. ${ }^{33}$ Así, los documentos testimoniales, esto es, aquellos en los que es objeto de prueba no por sí misma la declaración del otorgante, sino que el acontecimiento sobre el que esta informa, se someten a las reglas sobre valoración de la fuerza probatoria material, que presumen una credibilidad especial de su otorgante y asignan plena prueba al documento testimonial público sobre el acontecimiento manifestado. Respecto de los documentos testimoniales privados, su fuerza probatoria material se somete a la libre valoración del Tribunal, en la que resulta determinante la credibilidad de su otorgante para alcanzar convicción sobre el hecho declarado. ${ }^{34}$

Lampe se refiere al significado social del documento, que surge de la fuerza probatoria asignada dinámicamente a este en el tráfico jurídico y también en el proceso, donde el juez puede valorar libremente la prueba. ${ }^{35}$ Sin embargo, y en interés de la seguridad jurídica, la protección penal no puede abarcar todo ese significado social, sino que respecto de la preservación del valor probatorio del documento debe limitarse al significado probatorio objetivo determinable. Para la determinación del valor probatorio del documento conforme a reglas objetivas puede recurrirse a los preceptos del derecho procesal, en especial de la ordenanza procesal civil, de tal manera que la configuración de la protección jurídico-penal se encuentre dirigida fundamentalmente a asegurar las reglas probatorias del derecho procesal. ${ }^{36}$ En otro pasaje, Lampe sostiene respecto de la falsedad documental que mediante la protección del documento se procura incrementar "la seguridad del tráfico probatorio judicial y extrajudicial". ${ }^{37}$

Como puede observarse, ambos planteamientos discurren sobre la base que la prohibición de la falsedad documental sirve indirectamente a la producción correcta - "pura"- de pruebas en el proceso. Se legitima, por ende, en la medida en que contribuye a lograr el fin principal de todo proceso, que radica en la búsqueda de la verdad. Según ambos planteamientos, el documento prueba directamente la existencia de una declaración, sea de voluntad o testimonial, y esto tanto en el tráfico jurídico como en el proceso. Sin embargo, por definición la prueba recae

\footnotetext{
${ }^{32}$ LAMPE (1957), p. 9 con nota 4.

33 Ibid., p. 11 y s., con la expresión "documento tipo" (Tatbestandsurkunde) se refiere al documento dispositivo.

${ }^{34}$ Ibid., p. 12 y s.

35 Ibid., p. 15.

${ }^{36}$ Ibid.,p. 16.

37 Ibid.,p. 37.
} 
siempre sobre un hecho. Ergo, según la tesis de la función probatoria, el documento prueba el hecho de haberse emitido una declaración. Esto, que puede predicarse respecto de la prueba documental incorporada en un proceso, no vale sin más en el tráfico jurídico extraprocesal. Puesto que en el contexto de otorgamiento de un documento, este no prueba todavía nada. ${ }^{38}$ Desde ya, en la situación en que una persona otorga un documento dispositivo, por ejemplo, que fija un testamento, este no prueba ante nadie el hecho de su existencia. En todo caso, no se otorga con este fin. Resulta impreciso decir que un documento dispositivo prueba la existencia de la disposición. Pues el documento se confunde con el acto jurídico que contiene. Incluso al otorgarse un documento testimonial, por ejemplo, una declaración jurada ante Notario sobre el hecho de cumplir un requisito determinado o la no concurrencia de una inhabilidad, tampoco prueba ante nadie este hecho. Más bien, el documento testimonial se otorga para provocar la conducta jurídicamente relevante de otra persona, por ejemplo, una autoridad estatal. Lo anterior no es óbice a que, potencialmente, en el evento de un conflicto, tanto el documento dispositivo como el testimonial cumplan la función de probar la existencia de la declaración de voluntad o de conocimiento, respectivamente, en el marco de un proceso. Pero se trata de una función secundaria, que no es constitutiva del documento. ${ }^{39}$

\section{iv) La tesis de la función de garantía}

Respecto de la función de garantía (3.), esta tesis se encuentra ligada al nombre de Ingeborg Puppe. Rescata una idea basada en una comparación que formulara Kohlrausch del acto de otorgamiento de un documento, que una persona realiza en el tráfico jurídico, con el acto de promulgación de una ley, que el legislador lleva a cabo respecto del contenido de una ley aprobada. ${ }^{40}$ Así como este se convierte en ley cuando el legislador declara itajus esto, una expresión de pensamiento se convierte en una declaración en el tráfico jurídico cuando la persona plasma en ella también la manifestación de voluntad "esto vale como mi palabra". ${ }^{41}$ El significado de esta voluntad no consiste en destinar la declaración corporeizada a la prueba, sino que deriva de una forma de "lógica" jurídica según la cual aquello que uno pretende hacer valer como su palabra para los otros también debe valer contra uno mismo como su palabra: "la así denominada función de garantía del documento es una de sus consecuencias jurídicas, pero no su fin". ${ }^{42}$ Mediante el otorgamiento de un documento se expresa la voluntad de su otorgante no solamente en el sentido de que aquel sea signo de su declaración, sino también de que jurídicamente deba representarla, de tal forma que el otorgante queda vinculado tanto a la fijación de signos como a la declaración: "esta es la esencia del instituto jurídico de la documentación, en esta se basa la así llamada función de garantía del

\footnotetext{
38 SAMSON (1968), pp. 109 y ss.

${ }^{39}$ STEINMETZ (1991), pp. 46 y ss.

${ }^{40}$ Kohlrausch(1929), p. 336.

${ }^{41}$ Puppe (1972), p. 118 y s.

42 Ibid., p. 120.
} 
documento". ${ }^{43} \mathrm{El}$ ordenamiento jurídico y el tráfico basado en él -el tráfico jurídico-se atienen al documento como a la declaración que es representada por este, por voluntad del otorgante, con la consecuencia de que este último debe responder tanto por el documento como por la declaración: "esta función de garantía es el objeto protegido por la norma contra la falsedad documental". ${ }^{44}$

De este modo, Puppe aclara el significado del deber, cuya infracción funda el injusto del delito de falsedad documental. La tesis de la función de garantía logra así explicar el injusto desde la perspectiva del autor, pero por sí misma es insuficiente para dar cuenta del interés correlativo y jurídicamente protegido. ${ }^{45} \mathrm{En}$ otro lugar, Puppe sostiene al respecto que no se trata de un interés colectivo. El interés que se tiene en no ser engañado mediante declaraciones aparentes es un interés del individuo contra el cual se usa o ha de usarse el documento: "se trata de su libertad de disposición no afectada por engaños determinados". ${ }^{46} \mathrm{~A}$ esta concepción del bien jurídico protegido no se opone que el círculo de interesados sea indeterminado. No solamente el destinatario de la declaración o aquel que obtiene inmediatamente derechos, sino cualquiera que se orienta a la existencia de la declaración para sus decisiones jurídicamente relevantes, por ejemplo, el cesionario de un crédito documentado o el banco que debe financiar una compraventa escriturada. ${ }^{47}$

\section{v) El regreso del derecho a la verdad}

Recientemente, Jakobs ha reformulado este interés en los términos de un derecho. Parte de la acepción que Hegel le diera a la propiedad en el sentido de "esfera externa de la libertad de una persona". ${ }^{48}$ La propiedad en sentido amplio, entendida como arsenal de los medios utilizables para el desarrollo de la persona, por sí misma es inútil sin el conocimiento de las posibilidades concretamente abiertas, como, por ejemplo, un arsenal de armas no sirve concretamente al ataque o a la defensa, si su poseedor no sabe dónde está su enemigo, o una donación concreta no puede realizarse, si el filántropo no sabe de sus potenciales beneficiarios. Presupuesto de la libertad de una persona es, entonces, un determinado estado de información, que no puede verse diezmado por otro. ${ }^{49}$ Hecho este paralelo entre la disponibilidad de una cosa y la disponibilidad sobre información para la constitución de aquello que en sentido amplio y completo puede llamarse propiedad, se aclara de paso que el intento de formular el falsum como un delito no era un error categorial, sino que se

\footnotetext{
${ }^{43}$ Ibid., p. 123.

${ }^{44}$ Ibid.,pp. 175 y s.

45 Cfr. Ibid., p. 174: “Quien al emitir una declaración engaña sobre su identidad pretende ser jurídicamente eficaz y ejercer poder jurídico sin asumir responsabilidad por ello. Esto no puede ser tolerado por la comunidad jurídica, pues su ordenamiento depende de la imputabilidad de los actos a los sujetos jurídicos actuantes".

46 PuPPE (2013), \267, núm. marg. 8.

${ }^{47}$ Ibid.

${ }^{48}$ HEGEL (1970), \ 41.

${ }^{49}$ JAKOBS (2000), p. 11 y s.
} 
Rojas - Falsedad documental como delito contra el derecho a la verdad

encontraba dirigido a garantizar los presupuestos de la propiedad en dicho sentido, esto es: "la disponibilidad de cosas y de informaciones sobre el mundo en el cual se dispone, breve: disponibilidad e información". ${ }^{50}$

Jakobs advierte que no se trata de una garantía a la información correcta, existen, por cierto, instituciones que garantizan información correcta, por ejemplo, el registro conservador de bienes raíces. Por eso, habla de un "derecho a la no ocurrencia del engaño" y no simplemente de un derecho a la verdad, porque, siguiendo en este punto a Hälschner (vid. Supra2.b.i), nadie tiene un derecho ilimitado a obtener de otros en todas las relaciones información sobre la verdad fáctica. ${ }^{51}$ Desde la formulación del Estado liberal de derecho hacia 1800, el concepto de juridicidad Recbtlicbkeit- presupone no una cooperación recíproca entre los ciudadanos, sino solamente un respeto recíproco entre ellos. Se limita a lo negativo, la personalidad y su consecuencia de no lesionar, por lo que puede hablarse de un deber negativo, que se reconduce al neminemlaedere, "pero debe por lo menos prestarse atención positiva a la otra persona". ${ }^{2}$ De acuerdo con la premisa, según la cual en ningún delito puede derivarse la antijuridicidad de la conducta a partir del hecho de la producción del resultado -"teoría de la conducta típica como parte de la así llamada imputación objetiva"-, una mentira no se vuelve prohibida por causar un daño, sino cuando en la situación social puede esperarse la verdad o al menos la no ocurrencia del engaño. Un engaño no es tal por la manifestación de un hecho no verdadero, sino que en tanto lesiona un derecho a la no ocurrencia del engaño. ${ }^{53}$

Al precisar el alcance de este derecho, Jakobs se inclina por una concepción probatoria del delito de falsedad documental -\$2 267 StGB. Así, de una comparación de la oralidad con la escritura se deriva que esta última no ofrece una garantía incrementada de verdad. Pero tampoco la autenticidad se asegura mediante la escritura, pues uno puede considerar apto el medio de prueba o al contrario dudoso por la facilidad con que pueden crearse documentos inauténticos: esto atañe al lado cognitivo. El sujeto que documenta se presenta como persona porque documenta y no puede excusarse de las normas que lo rigen, por eso, es inherente a todo documento una pretensión de autenticidad. ${ }^{54} \mathrm{El}$ otorgante de un documento se vuelve doblemente activo, primero, en tanto emite una declaración con una pretensión de verdad, cuya mentira lo coloca en la misma posición que el declarante oral. Segundo, surge otro rol en la medida en que

\footnotetext{
${ }^{50}$ JAKOBS (2000), p. 12 (destacado original).

51 Ibid., pp. 6 y ss.; HÄLSCHNER (1868), \59 p. 369: "Nadie tiene un derecho ilimitado a obtener de otros en todas las relaciones información sobre la verdad fáctica, pero sí un derecho a no ser inducido a error intencionalmente con el fin del perjuicio en conocimiento del hecho", en una nota sobre la diferencia entre la estafa punible y la perseguible solo civilmente, inserta en el parágrafo 59 donde discute y rechaza la posibilidad de un engaño mediante una conducta puramente pasiva, aun cuando exista un deber de informar la verdad (p. 362 y s.).

52 JAKOBS (2000), p. 9 y s.; "freilich muss die andere Person immerhin positiv zur Kenntnis genommen werden" (destacado original).

${ }^{53}$ Ibid., p. 18.

${ }^{54}$ Ibid., p. 23 y s.
} 
observa su propia declaración y la documenta con la pretensión de producir un medio de prueba útil, esto es, correcto para el destinatario, de tal modo que si lo produce incorrectamente, se contradice a sí mismo. ${ }^{55} \mathrm{Los}$ roles de declarante $\left(1^{\circ}\right)$ y de documentador $\left(2^{\circ}\right)$ deben coincidir siempre en una misma persona. Así se aclara el injusto de la falsedad documental: "Quien declara por escrito se coloca a sí mismo en el rol de un asegurador probatorio y rompe este rol, cuando pone por escrito incorrectamente quien ha declarado". ${ }^{56} \mathrm{Si}$ alguien no quiere documentar de manera correcta, que lo deje, pero si se desliza en el rol del documentador, debe cumplirlo en forma correcta o abandonarlo de nuevo.

Esta concepción, explicita Jakobs, se aproxima a la tesis de Binding, pero la pureza de la producción de pruebas es reconocida solamente como un bien jurídico intermedio, puesto que la garantía sirve a la expectativa de no ser desorientado de una manera determinada. ${ }^{57}$ Hecha esta disquisición, es fácil aclarar de qué clase de posición de garante se trata aquí. El autor es garante no por la declaración, sino que por el medio de prueba, de la misma forma en que cualquiera resulta obligado al poner en circulación un producto, es decir, se trata de un deber de aseguramiento en el tráfico. También se puede decir: “(...) ha asumido frente al otro asegurar mediante un medio de prueba la identidad del otorgante". ${ }^{58}$

En la medida en que esta tesis se aproxima a la de Binding, se expone a la misma observación formulada respecto del uso del lenguaje probatorio para dar cuenta de una institución, cuyo significado trasciende el marco del proceso. Así, por ejemplo, al sostener que la declaración escrita, que el otorgante emite, se diferencia de la oral en que el declarante, mediante la escrituración junto con el señalamiento del otorgante y la posterior entrega, "pretende que una persona determinada, dígase él mismo, se ha fijado probatoriamente a una declaración determinada". ${ }^{59}$ La sugerente metáfora sobre el momento originario del documento, en la que el declarante se disocia, observa su propia declaración y la documenta con la pretensión de generar un medio de prueba útil para el destinatario, evoca la subordinación a los fines del proceso, en el marco del cual otro sujeto que recibe el documento podría reproducir, en el supuesto de haberse producido correctamente el documento en su origen, ahora literalmentela observación de la declaración ajena prestada originalmente por la persona de su otorgante.

Por otro lado, Jakobs defiende un concepto relativo de documento y en esa medida su tesis se distancia de la sostenida por Binding. Este concepto deriva del poder que tiene la persona de configurar autónomamente sus relaciones jurídicas y determinar frente a quien juega el rol de documentador. Dicho poder también es ejercido al otorgar un documento desde una institución pública, en la medida en

\footnotetext{
55 Ibid., p. 24.

${ }^{56}$ Ibid., p. 25 (destacado agregado).

${ }^{57}$ Ibid., p. 25.

${ }^{58}$ Ibid., p. 25 y s. (destacado agregado).

${ }^{59}$ Ibid., p. 23.
} 
Rojas - Falsedad documental como delito contra el derecho a la verdad

que se tenga también la facultad de delimitar el círculo de destinatarios de la declaración, por eso: "documentos con eficacia relativa". ${ }^{0}$ De este modo, el documento es concebido como un medio de prueba de la pretensión de una persona de producir efectos jurídicos. Su presupuesto es la autenticidad, entendida como señalamiento correcto del declarante. La autenticidad, entonces, se encuentra normativamente garantizada para posibilitar un "tráfico jurídico configurador de relaciones jurídicas". ${ }^{61}$

Esta tesis confunde, pero de manera consciente, la pretensión de producir un efecto jurídico con la consecuencia también jurídica de la decisión de fijación mediante el documento, de tal modo que cada vez que haya una decisión de fijación sin que exista aquella pretensión, no hay documento, por ejemplo, al escriturarse un acto jurídico que adolece de una causal de nulidad absoluta. ${ }^{62}$ Así, llega al siguiente concepto: "documento es toda declaración corporeizada que pretende producir efectos jurídicos (...) la expectativa garantizada mediante la prohibición de la falsedad documental reza: la documentación de la declaración prueba quién pretende producir un efecto jurídico". ${ }^{63}$ En otro lugar, Jakobs reitera: "Lo que en el caso de autenticidad configura un efecto jurídico, eso no puede ser presentado inauténticamente; así reza la prohibición de la falsedad documental [...] Nadie puede crear un documento con la pretensión de un efecto jurídico que no existe, de lo contrario lesiona su deber de aseguramiento". ${ }^{64} \mathrm{Y}$ precisa: "el mínimo de efecto jurídico es la vinculación a la declaración; otro efecto puede faltar, por ejemplo, en una oferta no aceptada, en la disposición de un sujeto no facultado sin consentimiento y sin ratificación $(\mathbb{\$} 185$ BGB)" ${ }^{65}$-BürgerlichesGesetz̧buch (Código civil alemán)-.

A partir de esta concepción resulta casi natural admitir el documento dispositivo, privado o público, puesto que precisamente en este se fija la configuración de relaciones jurídicas, radiquen estas en derechos y obligaciones entre particulares o en la constitución o reconocimiento de derechos a otro. También permite incluir el documento testimonial público con su prototipo de la declaración notarial, en la medida en que al dar testimonio del efecto jurídico documentado por las partes se vuelve al mismo tiempo configuración jurídica disimulada, esto es, un equivalente funcional del documento dispositivo. ${ }^{66}$ Pero, coherentemente, debe excluir los simples documentos testimoniales privados, puesto que estos no son de manera directa fuente de efectos jurídicos, sino que solo de forma indirecta, en la medida en que solo dan testimonio de un hecho jurídicamente relevante. ${ }^{67}$ Dice Jakobs:

\footnotetext{
${ }^{60} \mathrm{Ibid}$., p. 35; a renglón seguido aclara que la relatividad del documento no implica que un externo no deba respetarlo: "También documentos relativos gozan de protección absoluta" (p. 36; destacado agregado).

${ }^{61}$ Ibid., pp. 38 y ss.

62 Ibid., pp. 61 y ss., otros ejemplos.

${ }^{63}$ Ibid., p. 51 (destacado original).

${ }^{64}$ JAKOBS (2007), p. 230 y s. (destacado original).

${ }^{65}$ Ibid., p. 230 nota 17 (destacado original).

${ }^{66}$ JAKOBS (2000), pp. 48 y ss.

${ }^{67}$ Cfr. Ibid., pp. 52 y ss.
} 
"documentos que corporeizan efectos jurídicos son en el caso de su autenticidad fuente de esos efectos; por tanto, no puede estar en cuestión la verdad. Meras testificaciones son incluso en el caso de su autenticidad indicios directos o indirectos más o menos determinantes, no menos que otros medios de prueba indiciarios, que deben entonces compartir el mismo 'destino' jurídico-penal". ${ }^{68}$ La pregunta que resta en pie, es por qué en estas testificaciones escritas no concurre el mínimo de efecto jurídico consistente en la vinculación a la propia declaración. ${ }^{69}$ A esta pregunta, no ofrece una respuesta satisfactoria.

Sin perjuicio de lo anterior, la propuesta teórica de Jakobs tiene la virtud de mostrar aquello que en la falsedad documental como en cualquier delito no es perceptible sensorialmente, esto es, su antijuridicidad. Plantea en términos normativos un problema que usualmente se intenta abordar con categorías más bien descriptivas como "objeto material", "bien" jurídico o "peligro". Si en todo delito la antijuridicidad deriva de la contrariedad del significado de una conducta al significado de una norma, aquella se presenta en la falsedad documental en toda su pureza. Pues, de tener la materia alguna relevancia, esta se agota en la de ser soporte del documento, en papel o electrónico. Pero lo antijurídico de la falsedad documental deriva de que esta resulta contraria al significado del documento, no de una alteración de su soporte material. Aquí radica el mérito de esta propuesta, en situar el problema en su nivel correcto de análisis.

En el mismo plano pone en evidencia que este delito, como cualquiera, es relevante para el binomio de los deberes y derechos correlativos. Según Jakobs, el fundamento de la responsabilidad por la realización de este delito proviene de la infracción de un deber de aseguramiento en el tráfico. Pero el tráfico jurídico no es comparable a un mercado en el cual circulan y se intercambian bienes. Puesto que si un documento es lo contrario de un bien, ${ }^{70}$ entonces no es comparable a un producto alimentario o farmacéutico y, por tanto, tampoco su carácter deficiente puede provocar consecuencias similares a la persona de otro. Si se admite la comparación es solamente como una metáfora. Pero, además, desafortunada. El deber de aseguramiento en el tráfico y la asunción de una posición de garante son categorías de la parte general desarrolladas por la dogmática para establecer la equivalencia valorativa entre un delito de omisión y un delito de acción, cuyo concepto era en su origen básicamente causalista. ${ }^{71} \mathrm{La}$ falsedad documental es una figura eminentemente normativa, porque el concepto de documento es normativo. Metodológicamente, no es menester recurrir a esta categoría de la parte general como tampoco a ninguna de la teoría de la imputación objetiva para esclarecer el injusto de este delito.

\footnotetext{
${ }^{68}$ JAKOBS (2007), p. 232 y s. (destacado original).

${ }^{69}$ Cfr. la crítica de Puppe (2013), \267, núm. marg. 7 y s.

${ }^{70}$ Así, JAKOBS (1993), $2^{\circ}$ apartado, núm. marg. 6.

71 Vid. RoxiN (2003), \ 32 I, núm. marg. 1 y ss.
} 
¿Qué deber infringe, entonces, el autor de este delito? El deber de responder por su declaración, si ha decidido fijarla en un documento. Es una regla básica que debe observar toda persona que decide participar en el tráfico jurídico. ${ }^{72}$ En un Estado de derecho, empero, no se imponen deberes por mor del puro ejercicio de autoridad. La imposición de un deber encuentra su justificación en el reconocimiento de un derecho correlativo. ${ }^{73}$ Según Jakobs, en la falsedad documental no se trataría simplemente de un derecho a la verdad, sino que solamente de un "derecho a la no ocurrencia del engaño" (Recbtauf Unterbleiben von Täuschung). Con este nombre quiere acentuar que el deber correlativo del autor no es positivo, en el sentido de un deber a la cooperación mediante la comunicación de información correcta. Pero el costo de esta opción terminológica es alto, porque la denominación es abstrusa. El engaño es siempre una conducta del autor y esta es típica si infringe un deber negativo. Pero la víctima no tiene interés en que otro actúe conforme a las normas y deberes impuestos por el ordenamiento jurídico. El Estado sí tiene tal interés, en la medida en que se le reconozca un derecho a la obediencia de los ciudadanos. ${ }^{74}$ La persona sujeto de este derecho tiene interés en que su ámbito de organización no se vea diezmado por información incorrecta que pueda condicionar una decisión no libre, esto es, una conducta jurídicamente relevante que no es expresión de su libertad.

Ya a principios del siglo XX, Heinemann, en su estudio histórico sobre el crimen falsi en la doctrina italiana medieval tardía, había precisado el alcance de este derecho al plantear que el hombre necesita extraer conclusiones del mundo externo abierto a su observación, que influyen en su actividad: "presupuesto de la corrección de las conclusiones es que el mundo externo se abra a su observación de tal modo que las representaciones provocadas por aquellas se correspondan con las relaciones fácticas. Este atributo de lo observado es aquello que aquí se denomina veritas". ${ }^{75}$ Una mutatio veritatis es, por tanto, una acción mediante la que se introducen modificaciones en el círculo de los objetos de observación que son aptas para provocar representaciones que no se corresponden con las relaciones fácticas. ${ }^{76}$

A fines del mismo siglo, Kindhäuser reafirma este alcance del derecho a la verdad en el marco de la relación entre autor y víctima en el delito de estafa. Precisa el contenido de la pretensión a la verdad, en el sentido de que esta no es correlativa al deber de informar a otro: "la pretensión de verdad que aquí es relevante se dirige más bien solamente a que la declaración, que se emite o ha de emitirse, se corresponda con la verdad". ${ }^{77}$ La verdad se basa en el conocimiento y

\footnotetext{
72 Puppe (1972), pp. 174 y ss.; un principio básico del ordenamiento jurídico (p. 178).

${ }^{73}$ Cfr. FeUerbaCH (1847), \8 y ss.; JAKOBS (2008), pp. 651 y ss.

${ }^{74}$ Así, BiNDiNG (1922), pp. 81 y ss., 98 y ss.

${ }^{75}$ HeinemanN (1904), p. 12.

${ }^{76}$ Ibid.

77 KINDHÄUSER (1991), p. 403 nota 15: "Deberes de información son presupuesto de la responsabilidad por omisión, no obstante siempre también deberes a la expresión de la verdad" (destacado original).
} 
este se vehiculiza comunicativamente, por tanto, exige una prestación. Distingue entre derechos de libertad absolutos y relativos. Pertenecen al primer grupo los derechos basados en una pretensión de omisión, dirigida a cualquiera, por ejemplo, el derecho a la vida. En cambio, como el derecho a la verdad presupone una prestación, es un derecho de libertad relativo y, además, supeditado a la concurrencia de un fundamento. Sin perjuicio de que no existe un derecho absoluto a la verdad, "no obstante, la verdad es presupuesto de la libertad. No es posible el desarrollo libre sin orientación verdadera; solamente que, en principio, la orientación correcta es asunto de aquel que quiere desarrollarse (...)".78

En este sentido, el derecho a la verdad es un derecho de libertad secundario, pues la pretensión se supedita a la concurrencia de un fundamento. Kindhäuser distingue entre fundamentos heterónomos y autónomos. Pertenecen al primer grupo los deberes a la verdad impuestos en virtud de una ley o de una institución, por ejemplo, en el falso testimonio y el perjurio. En cambio, los deberes a la verdad autónomos son aquellos que dependen de la voluntad del destinatario y configuran el lado correlativo del uso de confianza, entre los que distingue, a su turno, el grupo del uso de confianza en beneficio propio frente a ciertos terceros, como los deberes de verdad sobre atributos del negocio jurídico en la etapa precontractual y de ejecución -relevantes en el delito de estafa-, y el grupo del uso de modalidades del tráfico jurídico que compensan riesgos específicos de no verdad mediante protección especial para la fluidez y el beneficio común, como "la garantía de la identidad del otorgante en el documento". ${ }^{79}$

Este esquema de los deberes de verdad coincide en lo fundamental con una propuesta que había esbozado Jakobs previamente en el marco de un trabajo sobre los delitos contra el honor, en el que intenta reconducir el fundamento de la protección del honor a los presupuestos de la autonomía, el desarrollo personal y la autopresentación (Selbstdarstellung). ${ }^{80}$ La realización de estos presupuestos es mayor mientras menos obstáculos se interpongan, entre los que se cuentan todas las falsificaciones de aquello a lo cual el sujeto se orienta. Así, se inserta el honor como valor de la persona en el contexto de los deberes de verdad, que Jakobs clasifica en tres grupos según el siguiente esbozo. ${ }^{81} \mathrm{El}$ deber a la expresión conforme a la verdad, que presuponen las normas de los parágrafos 153 -falso testimonio-, 154 -perjurio-, y 348 del StGB -falsedad en el cargo-, con fundamento en la competencia institucional. Dicho deber también puede emanar de la competencia

\footnotetext{
${ }^{78}$ Ibid., p. 403 (destacado agregado).

79 Ibid., p. 404.

80 Así lo reconoce KINDHÄUSER (1991), p. 404 nota 17: diferente fundamentación, pero conducente al mismo resultado que JAKOBS (1985 b), pp. 627 y ss.; valoración crítica de ambas propuestas en PAWLIK (1999), pp. 103 y ss.

${ }^{81}$ JAKOBS (1985 b), p. 633 nota 29.
} 
Rojas - Falsedad documental como delito contra el derecho a la verdad

por organización, en especial por asunción (1). ${ }^{82}$ En ausencia de un deber de expresión, existe un derecho general a la verdad en ámbitos determinados del contacto social, en los que el escepticismo y el control deben retroceder en favor de la fluidez de las interacciones. Se trata de ámbitos en los que existe una confianza protegida respecto de la identidad del otorgante en documentos $-\int 267$, del contenido de documentos generados bajo fe pública - \271, de la descripción de la prestación en el marco del intercambio de objetos valorados patrimonialmente $-\int 263$, o de la correcta ejecución de la atribución informal, como en el delito de injuria - $\iint 185$ y ss., StGB, en todos los cuales el derecho existe entre personas determinadas. Este derecho también existe, aún a falta de un deber de expresión, cuando un deber de actuar en favor del interés público se conecta a una expresión, como en el delito de denuncia falsa -\$ $164 \mathrm{StGB}(2)-$. Jakobs reconoce todavía un tercer grupo, en el que existe un derecho a la verdad, aún sin un deber de expresión y fuera de la restricción en ámbitos determinados del contacto social, en los casos límite de la posición de garante basada en una confianza especial, que surge del declarante que pretende frente al destinatario la corrección de una expresión en su favor, a la que debe también sujetarse, en consecuencia, cuando le desfavorece (3). ${ }^{83}$

\section{vi) Conclusión: un derecho negativo a la verdad}

De este modo, se afirman las bases para la aclaración del derecho involucrado en el delito de falsedad documental. Se trata de un derecho a la verdad. Este derecho tiene una faz negativa y una faz positiva. En su faz negativa, consiste en una pretensión a que en el ámbito de organización de una persona se reciban solo documentos existentes. Este derecho negativo a la verdad es correlativo a un deber también negativo que dota de contenido a la prohibición de la falsedad documental. ${ }^{84}$ Radica en el deber de no crear documentos falsos en el sentido de inexistentes inauténticos-. En su faz positiva consiste en una pretensión a que en el ámbito de organización de una persona se reciban documentos verdaderos, en el sentido de que el contenido de la declaración se corresponda con un hecho externo jurídicamente relevante. Este derecho positivo a la verdad es correlativo a un deber también positivo que dota de contenido a la norma que prohíbe la creación de documentos públicos existentes, pero cuyo contenido es falso en el sentido de no verdadero - no correspondencia-.

\footnotetext{
82 Según JAKOBS (1985 b), p. 633 nota 29, los deberes de expresión conforme a la verdad también pueden surgir de las normas de los parágrafos 138 -omisión de denuncia, y 323c -omisión de socorro, StGB, "pero no son naturalmente deberes de garante".

83 JAKOBS (1985 b), p. 633 nota 29; respecto del tercer grupo, PAWLIK (1999), pp. 142 y ss., desarrolla el alcance del derecho a la verdad basado en una relación de promesa para la configuración del delito de estafa.

${ }^{84}$ KAUFMANN (2006), p. 28: “(...), no existe un 'deber negativo’ en sentido estricto; la exigencia de deber solo puede caracterizarse como negativa aludiendo a su contenido, requiriéndose un no hacer, un omitir. La prohibición no es una 'norma negativa', sino una norma de contenido negativo de la que se derivan deberes de omitir. El acento negativo no recae en el deber, sino en lo debido".
} 
Esta distinción permite esclarecer el fin de protección de una norma que prohíbe la falsedad documental en el sentido de creación de un documento inexistente -inauténtico-. La protección de la autenticidad del documento tiene su fundamento en la protección del derecho negativo a la verdad como presupuesto de la libertad. ${ }^{85}$ Se trata, en consecuencia, de un derecho personal, esto es, cuyo titular es una persona, incluida una persona jurídica o del Estado. ${ }^{86}$

\section{c) Legitimación de la norma de protección a la verdad del documento público}

La protección de la verdad es necesaria solamente respecto de documentos testimoniales, esto es, que contienen una declaración sobre la ocurrencia de un becho jurídicamente relevante. Solo en relación con esta clase de documentos puede emitirse un juicio de verdad o falsedad en el sentido de correspondencia. Respecto de estos documentos rige estrictamente la teoría de la verdad como correspondencia. Además, las normas del ordenamiento jurídico civil o administrativo garantizan la verdad en esta acepción respecto de documentos públicos, no así en documentos testimoniales privados. ${ }^{87}$ En este sentido, Lampe dice que la protección de la corrección de contenido es necesaria solo en los documentos testimoniales y, entre ellos, solo aquellos que gozan de determinada fuerza probatoria material, esto es, según el Derecho vigente, los documentos públicos y determinados certificados. ${ }^{88}$ Esta constatación, sin embargo, no aclara el fundamento de legitimación de la protección a la verdad en esta clase de documentos.

Lúcidamente, Puppe hace ver que la teoría de la fe pública y su reformulación en los términos de la confianza general respecto de ciertas formas de autentificación, que resulta desacertada para explicar el fundamento de la protección a la autenticidad del documento, sí es plausible para aclarar el fundamento de la protección a la verdad del documento testimonial público. ${ }^{89}$ Sin embargo, los participantes en el tráfico jurídico confían en la corrección de la declaración contenida en un documento público, no porque se encuentre dotado de fe pública, sino porque la declaración ha sido documentada por una persona sujeta a un deber de verdad. En este sentido, la fe pública o confianza general es más bien un efecto reflejo del deber de verdad y no al revés, como se suele plantear, que el deber a la verdad deriva de la fe pública depositada en el documento público. ${ }^{90}$ Ergo, la fe pública o la confianza general como tales no pueden servir de fundamento de legitimación de una norma que protege la verdad del documento testimonial público.

\footnotetext{
${ }^{85}$ KINDHÄUSER (1991), p. 403 y s.

${ }^{86}$ JAKOBS (2007), p. 228; cfr. PupPE (2013) \267, núm. marg. 8.

${ }^{87}$ Cfr. Claro Solar (1939), pp. 670 y ss.

${ }^{88}$ LAMPE (1957), p. 17.

${ }^{89}$ Puppe (2013), \271, núm. marg. 3.

90 Puppe (2009), p. 8, 12.
} 
Pero tampoco el deber de verdad es suficiente fundamento. Su infracción configura el injusto del delito consistente en crear un documento testimonial público falso en el sentido de que su declaración no se corresponde con un hecho jurídicamente relevante. No obstante, en una concepción liberal del derecho penal, la imposición de un deber es correlativa a la protección de un derecho. Si se trata de un deber positivo a la verdad, entonces este no puede ser otro que el derecho positivo a la verdad. En este sentido se pronunciaría Paul Merkel a principios del siglo XX, al reformular la segunda prohibición de la tripartición de Binding (vid. supra 2.b.i) en los términos de un "derecho de cada uno a la verdad del contenido de documentos públicos con contenido jurídico relevante y de certificados de salud". ${ }^{1}$ Y Kindhäuser sostendría, a fines del mismo siglo, que se trata de un derecho a la verdad con un fundamento heterónomo, es decir, contemplado en una ley o derivado de una institución. ${ }^{92}$

Esta última distinción es relevante, porque "todo deber de verdad protegido jurídico penalmente es restringido en su alcance", lo cual vale para el deber del testigo en el proceso, pero también para el ciudadano y el funcionario que participan en el otorgamiento de un documento público. ${ }^{93}$ En este sentido, el esbozo sistemático de los deberes de verdad propuesto por Jakobs busca fijar los límites del derecho a la verdad. ${ }^{94}$ Sin embargo, el alcance del deber de verdad no es fijado por la propia norma penal, que le confiere protección. Se restringe a la verdad del documento testimonial público sobre un hecho jurídicamente relevante. Pero no es la propia ley penal la que determina si un hecho es o no jurídicamente relevante. Se trata, entonces, de normas jurídicas prepenales, de derecho privado o público, de derecho civil o administrativo. Estas normas determinan el contenido del deber de verdad y, de este modo, el alcance del tipo penal. En los términos del Art. 193 N. 4 CP, si un hecho es o no "sustancial" en este sentido, no lo determina el propio tipo penal. De ahí que se sostenga que aquí se trata de un tipo penal parcialmente en blanco, porque para determinar el contenido del deber de verdad es preciso recurrir a normas jurídicas prepenales, de derecho civil o administrativo, de derecho privado o público. ${ }^{95}$

Esta caracterización plantea un problema metodológico que no se presenta respecto de la norma que brinda protección a la autenticidad del documento. Para delimitar el injusto del delito mediante la determinación del contenido del deber, es preciso recurrir a normas jurídicas prepenales que fijan la relevancia jurídica del

\footnotetext{
91 Merkel (1902), p. 203 y s.; precisamente, la reformulación en un derecho subjetivo que a Binding, sin ningún fundamento, le parecía aberrante.

92 KINDHÄUSER (1991), p. 404.

${ }^{3}$ Puppe(2009), p. 9.

${ }^{94}$ JAKOBS(1985 b), p. 633 nota 29.

95 Puppe(2013), \271, núm. marg. 5, \348, núm. marg. 2, y Puppe (2009), p. 11: „§348 StGB ist nämlich ein verkapptes Blankettgesetz, das auf diejenigen Vorschriften verweist, die den Inhalt der Beurkundung bestimmen“.
} 
hecho, cuya verdad se protege mediante la norma penal. En cambio, respecto de la norma de protección a la autenticidad del documento, el problema se reduce a la pregunta de si es plausible recurrir a criterios jurídicos prepenales, en particular extraídos del derecho civil, para determinar la inautenticidad en determinados grupos de casos -en especial, de firma con nombre ajeno- o si esta debe verificarse materialmente, conforme a criterios jurídico-penales. ${ }^{96}$

\section{La estructura típica de los delitos de falsedad documental y de uso de documento falso}

\section{a) Premisa de orden material}

El regreso del derecho a la verdad, en su faz negativa y en su faz positiva, sirve para explicar el fundamento de legitimación de la protección a la autenticidad y a la verdad que brindan las normas de los artículos 193, 194 y 197 CP. Según se ha visto (vid. supra 2.a), el fin de protección de las normas del Art. 193 y del Art. 194 CP es doble, pues protegen tanto la autenticidad como la verdad del documento público, vale decir, el derecho a la verdad en ambas caras. En cambio, el fin de protección de la norma del Art. 197 CP es único, pues se reduce a la protección de la autenticidad del documento privado o mercantil, esto es, en relación con esta clase de documentos se protege el derecho a la verdad solamente en su faz negativa.

Ahora bien, en la sistemática del Código penal se insertan los artículos 196 y 198, sobre uso malicioso de documento falso, a inmediata continuación de los artículos 193 y 194 y del Art. 197 CP, respectivamente. Esta regulación sistemática permite afirmar que, por una parte, el fin de protección de las normas de los artículos 193, 194 y 196 CP es el mismo y que, por otra, el fin de protección de las normas de los artículos 197 y $198 \mathrm{CP}$ es el mismo. Mediante el primer plexo de normas se protegen, en consecuencia, los mismos intereses jurídicamente reconocidos: la autenticidad y la verdad del documento público -el derecho a la verdad en su faz negativa y positiva-. El interés jurídicamente protegido en conjunto por las normas de los artículos 197 y 198 CP es, en cambio, único: protección de la autenticidad del documento privado y mercantil -el derecho a la verdad en su faz negativa-.

\section{b) La estructura de los tipos de falsedad (artículos 193, 194 y 197 CP) y de los tipos de uso de documento falso (artículos 196 y 198 CP)}

Una vez aclarada esta premisa de orden material, corresponde abordar la estructura de los delitos descritos en estos tipos. Para estos efectos, es preciso realizar, en primer lugar, un ejercicio de comparación de la forma en que, por un lado, los tipos de los artículos 193, 194 y 197 describen el delito y, por el otro, de la forma

\footnotetext{
${ }^{96}$ Crítico de la accesoriedad al derecho civil STEINMETZ (1991), pp. 40 y ss., en casos de firma con nombre ajeno, por ejemplo, del representado con autorización de este, pp. 139 y ss.
} 
en que los tipos de los artículos 196 y $198 \mathrm{CP}$ describen el hecho punible. Los artículos 193, 194 y 197 CP comparten la misma forma de describir la conducta típica a partir de la frase "cometer falsedad en un documento", público o privado, ergo, establecen delitos de falsedad documental. Frente a este ejercicio de comparación, puede hacerse notar la diferencia que surge en el texto del Art. 197, que alude al "perjuicio de tercero", elemento que no aparece mencionado ni en el Art. 193 ni en el $194 \mathrm{CP}^{97}$. Sin embargo, lo anterior no obsta a que la conducta típica, tradicionalmente dicho, "el verbo rector", se describe de la misma forma, es decir, se trata en los tres tipos citados de una conducta de falsedad. Por su lado, los artículos 196 y 198 CP comparten la misma forma de describir el hecho punible mediante la frase "hiciere uso de instrumento falso", por ende, establecen delitos de uso malicioso de documento falso. En contra de este ejercicio de comparación, se puede hacer ver que por la remisión del Art. 198 al Art. 197 CP se torna en exigencia también del delito de uso malicioso de documento privado o mercantil falso el "perjuicio de tercero". 98 Sin embargo, el texto del Art. 198 reza "el que maliciosamente hiciere uso de los instrumentos falsos a que se refiere el articulo anterior", por ende, la remisión se hace expresamente a las clases de documento contempladas en el inciso $1^{\circ}$, cual es, el documento privado, y a las mencionadas en el inciso $2^{\circ}$ del Art. $197 \mathrm{CP}$, esto es, el documento mercantil.

Este simple ejercicio de comparación permite afirmar que la estructura típica de los delitos de falsedad documental contemplados en los artículos 193, 194 y 197 es la misma. Y que, por su parte, la estructura típica de los delitos de uso malicioso de documento falso previstos en los artículos 196 y $198 \mathrm{CP}$ es la misma. Lo anterior implica que los delitos de falsedad documental y los delitos de uso malicioso de documento falso constituyen diferentes formas de ataque a los mismos intereses jurídicamente protegidos. Para esclarecer la diferencia entre ambas formas de ataque, es necesaria la siguiente reflexión.

Mediante la sola realización de una conducta típica de falsedad no puede lesionarse ningún interés jurídicamente protegido. Si se trata de la protección de la autenticidad y de la verdad del documento público en las normas de los artículos 193, 194 y 196 CP, entonces estos intereses pueden verse lesionados recién cuando otro, el receptor del documento, adquiere conocimiento del documento público falso por ser inauténtico o por ser no verdadero. Lo mismo vale respecto de la protección de la autenticidad en las normas de los artículos 197 y 198 CP, esto es, el interés solo puede verse lesionado cuando el receptor del documento privado o mercantil adquiere conocimiento del carácter falso por inauténtico del documento. Pero para alcanzar este estadio de conocimiento falso es necesario que previamente se haga uso del documento falso, en el marco de una relación comunicativa entre el emisor y el receptor del documento. La sola falsificación de un documento público o privado puede mantenerse en la esfera puramente interna del sujeto, en todo caso, siempre

\footnotetext{
${ }_{97}^{97}$ Sobre la función que cumple este elemento en el Art. 197 CP, ROJAS (2014 a), p. 542 y s.

98 Así, GARRIDO (2008), p. 92 y s.
} 
en el ámbito previo a la lesión del bien jurídico. ${ }^{99}$ Dicho con otras palabras, para alcanzar el ámbito propiamente lesivo del interés jurídico protegido es necesaria la realización de otra conducta posterior a la falsificación del documento. Esta otra conducta que, por decirlo así, media entre la falsificación y la lesión al bien jurídico, consiste en hacer uso de un documento falso.

La digresión anterior, hasta ahora más bien fenomenológica, permite extraer la siguiente consecuencia respecto de la estructura típica de estos delitos. Los delitos de falsedad documental previstos en los artículos 193, 194 y 197 CP constituyen delitos de peligro a los intereses jurídicos respectivamente protegidos autenticidad y verdad del documento público, en el primer plexo de normas, solamente autenticidad del documento privado en la última norma-. En cuanto a la cuestión de si se trata de un delito de peligro abstracto o concreto, cabe tener presente la distinción que Jakobs formula en el sentido de que "un peligro es abstracto, cuando la peligrosidad general de una conducta determinada constituye el fundamento para la reprobación de toda conducta de esa clase (...) un peligro es concreto, cuando un bien presente (iperspectiva de la víctima!) se encuentra en peligro". ${ }^{100}$ Conforme a esta distinción, se trataría de un delito de peligro abstracto, puesto que en el momento en que se ejecuta la conducta típica de falsedad, no necesariamente hay presencia de un bien que pueda ponerse en peligro. ${ }^{101} \mathrm{En}$ cambio, los delitos de uso de documento falso contemplados en los artículos 196 y 198 CP configuran delitos de lesión a los intereses jurídicos respectivamente protegidos. Mientras que la realización de las conductas de falsedad se ubica todavía en el ámbito previo a la lesión del bien jurídico, el uso del documento falso implica materialmente la lesión al interés jurídico protegido. ${ }^{102}$

\footnotetext{
${ }^{99}$ Cfr. JAKOBS (1985 a), pp. 755-757, advierte que las consecuencias que se mantienen en la esfera interna del ciudadano, no pueden constituir un acto preparatorio punible, la tentativa o consumación de un delito: "Los delitos documentarios, incluida la falsificación de dinero, en sus variantes del hacer y falsificar son al menos sospechosos a la luz de esta máxima de privacidad" (p. 757).

${ }^{100}$ Ibid., p. 767 nota 20.

101 En este sentido, Wohlers (2000), pp. 307 y ss., distingue al interior de los delitos de peligro abstracto tres categorías, los delitos de "peligrosidad concreta" (1), el delito cumulativo (2) y el delito de preparación (3), caracterizado este último por tratarse de "conductas, cuyo riesgo potencial radica en que el propio actuante u otra persona puede conectarse al producto de la conducta en cuestión para la realización de fines delictivos" (p. 310), mencionado como ejemplo, entre otros, las modalidades alternativas del hacer y el falsificar del \$267 StGB.

102 Así, VORMBAum (2011), p. 179, sostiene: "La acción de falsedad documental propiamente típica debe verse en la variante del uso, pues solamente mediante esta modalidad de acción se lesiona efectivamente el bien jurídico protegido del $\ 267$ StGB. La incriminación del hacer y el falsificar, en cambio, son construcciones auxiliares para abarcar conductas que materialmente constituyen actos preparatorios" (destacado agregado); FREUND (2010), núm. marg. 227a, afirma: "existe un engaño en el tráfico jurídico, cuando se lesiona el derecho del engañado a una base correcta de asignación mediante el fingimiento de la autenticidad de un documento. Actúa para el engaño quien reconoce que su proyecto puede implicar la lesión del derecho descrita sea inmediatamente por una conducta propia o mediatamente por medio de la conducta de un tercero"; ERB (2014), \267, núm. marg. 196, sostiene que la alternativa del "hacer uso" implica, a diferencia de las alternativas del hacer y el falsificar, el ataque al bien jurídico; la acción de engaño, que el autor tiene en mira o que
} 
Rojas - Falsedad documental como delito contra el derecho a la verdad

Ahora bien, la reflexión precedente sobre la forma de ataque propia de la falsedad y la característica del uso malicioso de documento falso permite aclarar la estructura común de los tipos de falsedad y de los tipos de uso de documento falso. La forma en que los tipos de los artículos 193, 194 y 197 describen la conducta prohibida surge de la frase "cometer falsedad en un documento" mediante alguna de las modalidades previstas en los numerales $1^{\circ}$ a $8^{\circ}$ del Art. 193 CP. Los tipos reducen la descripción del hecho punible a la conducta típica de falsedad documental. El tipo se realiza completamente cuando se ejecuta en forma íntegra la conducta típica. Se trata, entonces, de delitos de mera actividad.

En cambio, los tipos de uso malicioso de documento falso de los artículos 196 y 198 CP, que desde un punto de vista material constituyen delitos de lesión, exigen para su realización completa al menos que el receptor del documento falso adquiera conocimiento de este. Pero este estado de conocimiento falso del receptor presupone que el autor ejecute una conducta que posibilite este error. Ergo, el tipo de uso malicioso presupone, por una parte, la realización de una conducta típica de hacer uso por parte del autor y, por otra, la ocurrencia de un error en el receptor del documento falso, esto es, dos momentos diferenciables en el iter criminis. En consecuencia, y a diferencia que en los tipos de falsedad, es posible que el autor acabe la conducta típica de hacer uso, sin que se produzca un error y, por lo tanto, sin que se complete el tipo. En este sentido, los tipos de uso malicioso de documento falso pueden calificarse de delitos de resultado. ${ }^{103}$

efectivamente ha realizado en los casos de la tercera alternativa, corresponde al "uso" del documento inauténtico, se trata con el empleo del falso, en definitiva, del "ataque al bien jurídico específico del delito" (núm. marg. 203); las tres citas precedentes se han descontextualizado intencionalmente, pues todas se refieren al alcance del elemento subjetivo específico del tipo "para el engaño en el tráfico jurídico” del \267 StGB, en cuyo párrafo $1^{\circ}$ se contemplan las alternativas típicas del hacer y falsificar, pero también del hacer uso, por lo que dicho elemento subjetivo es común a las tres alternativas de conducta típica; la tesis que se sigue, básicamente, es que el "engaño en el tráfico jurídico”, cuya realización se exige por el \ 267 StGB solamente en el plano subjetivo, debido a la regulación separada del tipo de falsedad y del tipo de uso en el Código penal, describe el injusto del delito de uso malicioso de documento falso.

103 En este sentido, GARRIDO (2008), p. 92 y s., señala respecto del tipo del Art. 198 que "es un delito de resultado, de lesión, que requiere para perfeccionarse que una persona haya sufrido un perjuicio con motivo de esa conducta, perjuicio que no necesariamente ha de ser de índole patrimonial" (destacado original); pero ¿de qué índole puede ser un perjuicio no patrimonial, que sea consecuencia del empleo malicioso de un documento falso y que no configure la lesión a otro interés jurídico individual o colectivo expresamente contemplada en otro tipo -ej. calumnia en el Art. 412 o la presentación de medios de prueba falsos ante un tribunal en el art. 207 CP-? Respecto del tipo del Art. 196 CP, el mismo autor sostiene que "este delito consiste en la acción de usar el documento, y usar para estos efectos tiene un sentido amplio, no se requiere que cause un perjuicio, pero sí es necesario que se emplee el documento como tal. Un uso de otra índole, sea como simple papel u otro independiente de su calidad de documento público, es atípico. Lo que se ampara es la fe pública, y esta resulta afectada únicamente cuando el usuario emplea el documento mendaz como verdadero, aunque no perjudique a una persona determinada con ello" (p. 85 y s.); de este pasaje es posible colegir el alcance de un "perjuicio de índole no patrimonial", este consiste 


\section{Iter criminis sin solución de continuidad}

El análisis previamente desarrollado permite abordar una cuestión que apenas ha sido tratada en la doctrina nacional. Esta dice relación con la delimitación del iter criminis de los delitos de falsedad documental (artículos 193, 194 y 197 CP) y de los delitos de uso malicioso de documento falso (artículos 196 y 198 CP).

\section{a) Fase de ejecución de los delitos de falsedad documental (artículos 193, 194 y 197 CP)}

La aclaración previa sobre la estructura de los tipos de falsedad documental, en el sentido de que se trata aquí de delitos de mera actividad, permite delimitar la fase de ejecución de estos delitos de la siguiente manera:

\begin{tabular}{|l|l|l|l|}
\hline \multicolumn{4}{|l|}{ Realización de la conducta típica } \\
\hline Decisión a la & Elaboración de & $\begin{array}{l}\text { Creación de } \\
\text { inmediata }\end{array}$ & $\begin{array}{l}\text { Acceso de un tercero } \\
\text { borrador de }\end{array}$ \\
elaboración del & documento falso & documento falso \\
borrador de & (con al menos uno & elementos) & \\
documento falso & de sus elementos & & \\
& constitutivos) & & \\
\hline
\end{tabular}

En el caso del presente tipo, se trata de un delito de falsedad documental, que consiste en la creación de un documento falso, por tanto, se comienza a realizar propiamente el tipo cuando el dolo se manifiesta de forma externa en la elaboración de al menos uno de los elementos constitutivos de un documento, por ejemplo, su contenido declarativo o su atribución a un sujeto. ${ }^{104}$ Pero también puede configurarse el principio de ejecución cuando el último acto que alcanza a realizar el sujeto es inmediatamente previo a la realización típica, en la medida en que este adopte la decisión a cometer el hecho punible. ${ }^{105}$ Por tanto, el umbral de la tentativa puede fijarse en un momento inmediatamente previo al comienzo de realización de

en emplear el documento como tal, es decir, usar un documento falso como si existiera y, en el caso del documento público, emplear un documento falso como si fuera verdadero.

104 Sobre los elementos que deben concurrir para estar en presencia de un documento, RoJAS (2014 a), pp. 530 y ss.

105 Cfr. Murmann (1999), pp. 8 y ss., hace ver con razón que dolo, en estricto rigor, solo puede formarse cuando el autor realiza la conducta típica, antes de ese momento, se trata estructuralmente de actos preparatorios, aun cuando estos se encuentren unidos al tipo por un nexo de inmediatez; en esta fase inmediatamente previa al tipo, dolo en el sentido de conocimiento referido a la ejecución del acto preparatorio no es suficiente para legitimar el castigo a título de tentativa, para este efecto, debe además formarse en el autor la intención de proceder a la realización de la conducta típica (p. 11). 
Rojas - Falsedad documental como delito contra el derecho a la verdad

la conducta propiamente típica, en la medida en que el sujeto adopte la decisión a su realización completa. ${ }^{106}$

En cuanto al momento consumativo del delito de falsedad documental, este podría fijarse al completar la creación del documento falso con todos sus elementos, sin embargo, este momento puede permanecer frecuentemente en la esfera interna del sujeto. ${ }^{107}$ Para que se consume, el hecho debe alcanzar relevancia intersubjetiva, lo que ocurre desde ya cuando el propio autor de la falsedad se dispone inmediatamente a hacer uso del documento falso, por ejemplo, enviándolo a su destinatario. Pero si no es el caso, dicha relevancia se alcanza también cuando el sujeto vuelve accesible el documento falso a un tercero, que normalmente será el destinatario, pero que también puede ser otro sujeto que pretenda usarlo antijurídicamente en el tráfico jurídico. Este es el momento de consumación del delito de falsedad documental. En cualquiera de esos momentos, el hecho traspasa la esfera interna del autor y alcanza la externa de otro sujeto, aun cuando no se produzca todavía una lesión al interés jurídico protegido ni tampoco una "puesta en peligro concreto" de este. Lo materialmente determinante es que la realización de la conducta implique efectivamente un cuestionamiento a la prohibición de crear un documento falso, que subyace al tipo de falsedad -Art. 193, 194 o 197 CP-.

\section{b) Fase de ejecución de los delitos de uso malicioso de documento falso (artículos 196 y $198 \mathrm{CP}$ )}

En cuanto a los delitos de uso malicioso de documento falso, si se parte de la premisa que la estructura del tipo corresponde a un delito de resultado, la fase de ejecución puede dividirse en dos etapas. En una se realiza la conducta típica y en la otra se produce el resultado, del siguiente modo:

\begin{tabular}{|c|c|c|c|c|}
\hline \multicolumn{3}{|c|}{ Realización de conducta típica } & \multicolumn{2}{|l|}{ Resultado típico } \\
\hline \multirow{2}{*}{$\begin{array}{l}\text { Decisión al } \\
\text { inmediato } \\
\text { envío/ } \\
\text { entrega/ } \\
\text { presentación } \\
\text { del } \\
\text { documento } \\
\text { falso }\end{array}$} & \multirow{2}{*}{$\begin{array}{l}\text { Envío/ } \\
\text { entrega/ } \\
\text { presentación } \\
\text { de } \\
\text { documento } \\
\text { falso }\end{array}$} & \multirow[t]{2}{*}{$\begin{array}{l}\text { Recepción de } \\
\text { documento } \\
\text { falso }\end{array}$} & \multirow[t]{2}{*}{$\begin{array}{l}\text { Conocimiento } \\
\text { de documento } \\
\text { falso }\end{array}$} & Error de otro \\
\hline & & & & $\begin{array}{l}\text { Conducta } \\
\text { jurídicamente } \\
\text { relevante de } \\
\text { otro }\end{array}$ \\
\hline
\end{tabular}

\footnotetext{
106 MurmanN (1999), p. 25, pone de relieve que con el requisito de "inmediatez" se designa un criterio descriptivo, lo materialmente decisivo es la pregunta por la medida en que se realiza el injusto (del hecho tentado) merecedor de pena antes de la realización de la acción típica.

107 Cfr. JAKOBS (1985 a), p. 756, aquí se encuentra la legendaria frase de Jakobs: "El derecho penal del enemigo optimiza protección de bienes jurídicos, el derecho penal del ciudadano optimiza esferas de libertad".
} 
El esclarecimiento de la fase de ejecución de este delito exige previamente una reflexión en el plano subjetivo. Esta gira en torno a la siguiente pregunta: ¿Por qué el legislador del siglo XIX exige "malicia" en los tipos de uso de documento falso, al mismo tiempo que omite esta exigencia en los tipos de falsedad? Si hubiera pretendido de este modo cerciorarse que el autor conociera el carácter falso del documento, hubiese incluido simplemente la mención "a sabiendas", como sucede, por ejemplo, en el tipo de presentación de medios de prueba falsos ante tribunal del Art. 207 CP. Sin embargo, no se ha satisfecho con esta exigencia subjetiva, ¿por qué?

Mientras que es concebible la realización de una hipótesis de falsedad en relación con un sujeto aún indeterminado, resulta difícilmente pensable hacer uso de un documento falso respecto de un otro innominado. Se envía o presenta un documento siempre a un sujeto determinado. Si el documento es una forma de comunicación, entonces su uso se produce en el marco de una relación comunicativa, esto es, entre un emisor y un receptor del mensaje. ${ }^{108}$ Se hace uso de un documento falso para engañar a otro, ya sea para hacerle creer que existe un documento, cuando en realidad no existe ninguno, o para hacerle creer que su contenido es verdadero, cuando en verdad este es falso. Pero este engaño tampoco es un fin en sí mismo. Como dijera irónicamente Binding, este engaño no es académico, "sino que para un fin práctico y jurídicamente relevante". ${ }^{109}$ Este fin consiste en mover al receptor del mensaje a la realización de una conducta jurídicamente relevante ${ }^{110}$. Así se explica la exigencia de "malicia", esto es, en el lenguaje moderno de la teoría del delito, de dolo directo, en el sentido de que se hace uso de un documento falso para provocar una conducta jurídicamente relevante del destinatario mediante el error.

\footnotetext{
${ }^{108}$ SAMSON (1968), pp. 33 y ss., fue el primero en poner de relieve este carácter del documento, con una amplia investigación realizada desde la semiología; pocos años después, PUPPE (1972), pp. 18 y ss., profundiza en la misma dimensión.

${ }^{109}$ BINDING (1904), p. 242.

110 Puppe (2013), \267, núm. marg. 100: "El autor actúa en el tráfico jurídico, cuando pretende mover al destinatario del engaño a alguna conducta jurídicamente relevante"; el $\int 271$ párrafo 2 StGB, sobre falsa documentación mediata en registros o documentos públicos, contempla también la modalidad de hacer uso "para el engaño en el tráfico jurídico", por lo que PuPPE (2013), \ 271, núm. marg. 48, sostiene que esta modalidad típica debe entenderse en el mismo sentido que en el $\$$ 267 StGB; sin embargo, el contenido del engaño y del error no puede ser el mismo, no obstante que la estructura del elemento subjetivo sea la misma, debido a que el fin de protección de la norma del $\$$ 271 - protección de la verdad- es distinto que el del $\int 267$ StGB -protección de la autenticidad-; si, como sostiene PupPE (2013), \267, núm. marg. 99, respecto de este tipo que, "según su contenido, el engaño debe radicar solamente en que el documento sea auténtico”, entonces, el mismo en el $\$$ 271 párrafo 2 StGB no puede sino recaer en que el documento público sea verdadero.
} 
Rojas - Falsedad documental como delito contra el derecho a la verdad

\section{i) Principio de ejecución del delito de uso malicioso de documento falso (artículos 196 y $198 \mathrm{CP}$ )}

Esta disquisición en el plano subjetivo permite aproximarse a una delimitación de la fase de ejecución de este delito. Para provocar un error en otro mediante un documento falso, es menester que una persona previamente lo reciba. La recepción del documento falso, a su turno, presupone que el autor lo envíe o entregue. Si lo determinante es la recepción del mensaje y no meramente de su soporte, entonces esta también se puede producir mediante la simple presentación del documento falso a otro. Enviar, entregar o presentar son distintas formas de hacer uso de un documento. ${ }^{111}$ Por tanto, son diferentes modos de realización de la conducta típica del delito de uso malicioso.

De esta manera, y en aplicación de los principios de la teoría de la tentativa, es posible fijar el comienzo de ejecución de este delito en el momento en que el autor adopta la decisión de realizar dicha conducta y la manifiesta en forma externa al menos en un acto inmediatamente previo a la realización típica. ${ }^{112}$ Es decir, desde la perspectiva del autor, es necesario que adopte la decisión de realizar la conducta típica en cualquiera de los modos antes reseñados. Si esta decisión se traduce ya en la realización de cualquiera de estos modos, por ejemplo, en el envío del documento falso, entonces sin duda hay principio de ejecución. Pero este también puede configurarse cuando dicha decisión alcanza a manifestarse externamente en un acto previo a cualquiera de los modos de realización de la conducta típica.

\section{ii) Consumación del delito de uso malicioso de documento falso (artículos 196 y $198 \mathrm{CP}$ )}

Ahora bien, respecto del momento de consumación, existen dos alternativas que implican la realización del contenido de injusto de este delito. Ambas son coherentes con la premisa de que se trata aquí de la lesión al interés jurídicamente protegido y que este tipo describe un delito de resultado. El momento consumativo puede fijarse en el estado de error del otro o en la realización de una conducta jurídicamente relevante por parte de este. ${ }^{113}$ Ambos momentos son consecuencias posibles de la realización de la conducta típica de hacer uso de un documento falso, solamente que uno -el error- se sitúa antes en el itercriminis. Antes del error pueden identificarse los momentos de la recepción y del mero conocimiento de la presencia del documento, pero ambos son en sí mismos irrelevantes. La recepción del documento normalmente marca la finalización de la realización de la conducta típica, mientras que la toma de conocimiento de la presencia del documento es un paso previo al

\footnotetext{
111 Cfr. SAMSON (1968), pp. 114 y ss.

112 Cfr. Roxin (2003), \29, núm. marg. 126 y ss., sobre la "teoría del acto intermedio"; sobre la punibilidad de la tentativa de falsedad documental, el mismo (2003), \29, núm. marg. 343.

113 Cfr. JAKOBS (2000), p. 90 y s. con nota 148.
} 
error propiamente tal. Pero ni una ni la otra fundamentan el injusto de este delito y muchas veces penden de la mera casualidad. ${ }^{114}$

Si hacer uso de un documento falso se interpreta en el sentido de una conducta de engaño en el tráfico jurídico, entonces basta con la realización de la consecuencia propia del engaño que es el error de otro. Exigir para la consumación que este último efectivamente realice una conducta jurídicamente relevante, condicionada por un error, por ejemplo, una disposición patrimonial o una decisión relevante para otros intereses jurídicos de la persona, no tiene mayor asidero en el texto de la ley, que solo se refiere al "hacer uso". ${ }^{115}$ La pregunta por la consumación depende, entonces, solamente del alcance que se le puede dar a la palabra uso.

Como sostiene Jakobs respecto del delito de falsedad documental, este se consuma cuando el quiebre del derecho se ha manifestado en el resultado, esto es, con la desorientación. ${ }^{116} \mathrm{El}$ problema que plantea el $\ 267$ del StGB radica en que sanciona con la misma pena la falsificación del documento, que se ubica en el ámbito previo a la lesión, y el hacer uso del documento falso, que se sitúa en la fase ya propiamente lesiva del bien jurídico, por lo que se habla de una suerte de "delito de emprendimiento" (vid. definición del $\left.\int 11 \mathrm{~N} .6 \mathrm{StGB}\right) .{ }^{117}$ Esta forma de regulación legal, cuyo origen histórico se remonta a la primera versión de esta disposición en el Reichsstrafgesetz̧buch de 1871, que consagraba un delito de dos actos -falsedad y uso-, constriñe a la doctrina alemana a buscar una solución interpretativa que pueda compensar en el plano subjetivo el déficit regulativo que implica castigar con la misma pena un acto preparatorio -la falsificación- y una conducta propiamente lesiva -hacer uso-. ${ }^{118} \mathrm{Si}$ originalmente la punibilidad de la

114 Cfr. BINDING (1904), pp. 249 y ss.

115 De lege ferenda JAKOBS (2000), p. 90 nota 148, observa que el legislador también puede elegir un momento posterior para la realización típica, por ejemplo, en la conducta bajo desorientación, pues a la desorientación misma como suceso "interno" le falta relevancia social y, además, muchas veces puede restar sin consecuencias: "¿A quién le sirven todas las libertades sobre las cuales el sujeto cree estar orientado?".

${ }^{116}$ JAKOBS (2000), p. 90.

117 Puppe (2013), \267, núm. marg. 99, señala que con el elemento del tipo "para el engaño en el tráfico jurídico" se describe propiamente la lesión del bien jurídico, pero en la medida en que la ley se satisface con la realización de este elemento en el tipo subjetivo, "convierte la falsedad documental en un delito impropio de emprendimiento"; JAKOBS (2000), p. 91, se refiere a un "pequeño" delito de emprendimiento, que abarca la tentativa inacabada y la acabada seguramente reversible; DENCKER (2010), p. 289 y s., habla de delitos disimulados ("verkümmerte") de dos actos y de resultado cortado, porque se hace uso del documento falso para engañar en el tráfico jurídico, sin que sea menester que este engaño se realice efectivamente, por eso califica esta alternativa de "resultado cortado"; mientras que las alternativas del hacer y el falsificar, que más bien son actos preparatorios en relación con el engaño, serían de dos actos "disimulados", ya que se realizan con la intención de luego usar el documento falso y hacer uso es otro acto, sin que se exija la realización copulativa de ambos.

118 LENCKNER (1967), p. 1892 y s., aboga por una interpretación amplia del elemento subjetivo específico del tipo "para el engaño en el tráfico jurídico" y equivalente para las tres alternativas del 
Rojas - Falsedad documental como delito contra el derecho a la verdad

conducta de falsedad se supeditaba a la efectiva realización del uso, actualmente se contempla la primera conducta como alternativa típica del hacer uso, pero castigada con la pena propia de este, esto es, de la consumación material. ${ }^{119}$

Debido a que en la tradición del Código penal chileno los tipos de uso malicioso de documento falso siempre se han contemplado de modo separado y a continuación de los tipos de falsedad, dicho constreñimiento interpretativo no se presenta. De tal modo que el momento de consumación puede sin más definirse en la producción del error como consecuencia de hacer uso del documento falso. También es plausible sostener que el delito se consuma cuando en forma efectiva se realice una conducta jurídicamente relevante, condicionada por el error. Pero si se parte de la premisa que la norma del Art. 196 protege, al igual que la del Art. 193 y $194 \mathrm{CP}$, el derecho a la verdad en su faz negativa y en su faz positiva, mientras que la del Art. 198 protege, al igual que el Art. 197 CP, solamente el derecho negativo a la verdad, entonces es coherente identificar el momento de lesión a los presupuestos fácticos del ejercicio de este derecho cuando el otro incurre en el error de creer falsamente que el documento es auténtico o verdadero, en el primer caso, o que es auténtico en el sentido de existente, en el segundo.

\section{Conclusiones}

a) Bajo la tesis de la fe pública, la forma tradicional de abordar la discusión sobre el fin de protección de las normas sobre falsedad documental ha permanecido en la oscuridad. La técnica legislativa tanto del Código penal chileno (Art. 193) como del Código penal español (Art. 390), que antepone el tipo sobre falsedad cometida por un empleado público en un documento público en el sistema de normas, ha consolidado este estado de oscuridad. Esta norma brinda protección tanto a la autenticidad como a la verdad del documento público y, en consecuencia, mežcla

\footnotetext{
hacer, falsificar y hacer uso; en reflexiones de lege ferenda VORMBAUM (2011), p. 179 y s., sigue una interpretación amplia en la alternativa del hacer uso, ya que solamente mediante esta modalidad de acción se lesiona efectivamente el bien jurídico protegido del $\$ 267$ StGB, mientras que respecto de las alternativas típicas del hacer y falsificar, que materialmente constituyen actos preparatorios, favorece una interpretación restringida de este elemento a la "intención de mover con el documento falso producido a una persona a una conducta jurídicamente relevante. En el núcleo propio de la acción de falsedad documental, en el uso, no se requiere de este correctivo"; en este sentido, DENCKER (2010), pp. 290 y ss., califica la modalidad del hacer uso como "tentativa acabada", por lo que basta obrar dolosamente con el pronóstico de "una conducta jurídicamente relevante de la víctima condicionada por el engaño” (p. 290 y s.), mientras que en las alternativas del hacer y el falsificar se trataría de "tentativa inacabada", por lo que deben realizarse con la decisión a luego uno mismo hacer accesible el documento al sujeto a engañar o entregarlo a otro, de quien se espera seriamente lo mismo, es decir, al menos con el pronóstico seguro del "uso engañoso" en manos propias o ajenas y respecto de la posibilidad de la conducta de la víctima bajo error, basta dolo eventual (p. 292 y s.).

119 Respecto de la historia de la disposición original, PRECHTEL (2005), pp. 43 y ss.; muy crítico de la disposición vigente, FRISTER (2011), p. 317 y s.
} 
intereses de protección diversos. La regulación sistemática propia de esta tradición jurídica ha constreñido a la doctrina nacional y española a proponer una justificación conjunta de la protección a ambos intereses. El concepto de $f e$ pública y su reformulación en la tesis de la confianza general, así como el concepto de seguridad del tráfico jurídico, son lo suficientemente comprehensivos y elásticos para este efecto. Pero en este desarrollo conceptual se pierde de vista que los intereses de protección en juego son diversos y que, por consiguiente, exigen una fundamentación también distinta. Dicho estado de oscuridad se manifiesta en la forma en que, particularmente, la doctrina española recurre a la teoría de las funciones para ofrecer una justificación de la norma del Art. 390 del Código penal español de 1995. No acusa recibo de que esta teoría se ha desarrollado en el ámbito de la doctrina alemana para esclarecer el fundamento de la norma del $\int 267$ StGB, cuyo fin indudablemente se reduce a la protección de la autenticidad del documento, público o privado.

b) Dicho con otras palabras, en el ámbito de la doctrina alemana resulta claro que, por un lado, la norma del $\$ 267$ StGB protege la autenticidad del documento y que, por el otro, las normas de los $\iint 271,348$ StGB protegen la verdad de la documentación pública. La regulación sistemática del StGB es, en comparación con la del Código penal chileno y del Código penal español, más diferenciada. Dicha técnica legislativa, al separar ya a nivel normativo la protección de intereses diversos, evita la confusión que se produce en el ámbito de la doctrina nacional y española. La discusión se desata en torno al fundamento de la protección a la autenticidad del documento en el marco del $\$ 267$ StGB.

c) A lo largo del trabajo precedente, se intenta poner en orden esta discusión y, por consiguiente, se revisa detenidamente la teoría de las funciones a propósito de la norma que brinda protección a la autenticidad del documento. En la dirección marcada por Jakobs en el umbral del presente siglo, que opera un decidido regreso a la tesis sostenida por Feuerbach dos siglos antes sobre el fundamento de legitimación de cualquier norma penal, se vislumbra también un regreso del derecho a la verdad, que Binding había declarado finalmente muerto. El fundamento de una norma que brinda protección a la autenticidad de un documento, público o privado, radica en un derecho negativo a la verdad y que, como tal, exige amplia protección -un derecho de libertad absoluto-. De ahí que esta norma abarque cualquier clase de documento y por eso también que la discusión principal en torno a esta norma dice relación casi exclusivamente con el concepto de documento.

d) En cambio, el fundamento de la norma que brinda protección a la verdad de la documentación pública consiste en un derecho positivo a la verdad, correlativo a un deber que siempre es restringido - un derecho de libertad relativo-. De ahí la limitación de su alcance a cierta clase de documentos públicos y solamente respecto de determinados contenidos fácticos jurídicamente relevantes. 
Rojas - Falsedad documental como delito contra el derecho a la verdad

e) Sobre la base de este análisis previo se esclarece la estructura de los tipos de falsedad y de los tipos de uso malicioso de documento falso. En este punto es la regulación del StGB la que evidencia un déficit patente, que comparativamente no se presenta en la tradición del Código penal chileno y del Código penal español. Este déficit regulativo radica en la consagración de una suerte de delito de emprendimiento en el mismo tipo del $\int 267$ párrafo $1^{\circ}$, que somete a la misma pena la realización de la falsedad, ubicada todavía en el ámbito previo a la lesión del bien jurídico, con el hacer uso del documento falso, que ya conlleva esta lesión. Dicho déficit tiene una explicación histórica, que se remonta a la antigua versión del $\int 267$ en el Reichsstrafgesetzbuch de 1871. Tal defecto se ve agravado por la inserción de un elemento subjetivo específico del tipo, descrito con la frase para el engaño en el tráfico jurídico, cuya configuración se exige tanto en la realización de la falsedad como al hacer uso del documento falso. De tal modo que queda entregado a la definición de la jurisprudencia y de la doctrina, si el contenido de este elemento es o no el mismo en la realización de conductas típicas -la de la falsedad y la del hacer uso- situadas en momentos materialmente distintos del iter criminis.

f) Este déficit regulativo no se presenta ni en el Código penal chileno ni el Código penal español, que siempre han previsto el tipo de uso de documento falso de modo separado y a continuación del tipo de falsedad. En este punto, es la regulación sistemática propia de esta tradición jurídica la que es más diferenciada, en comparación con la del StGB. Pues separa ya a nivel normativo el tipo de falsedad del tipo de uso de documento falso, técnica legislativa que libera a la doctrina de la necesidad de buscar correctivos a nivel interpretativo. Esta técnica legislativa en este aspecto diferenciada permite, por una parte, una reconstrucción dogmática también diferenciada del injusto típico del delito de falsedad documental y del delito de uso malicioso de documento falso, en el sentido de concebir el primero como un delito de peligro y el segundo como un delito de lesión. Por otra parte, esta reconstrucción dogmática diferenciada a nivel de injusto típico permite esclarecer el tipo subjetivo por separado de ambos delitos.

g) Esta reconstrucción dogmática diferenciada del injusto en el plano del tipo objetivo y del tipo subjetivo de ambos delitos permite, finalmente, una delimitación adecuada del iter criminis, según la cual el delito de falsedad documental se consuma en el momento exactamente anterior al comienzo de ejecución del delito de uso malicioso de documento falso. Dicho en otros términos, el comienzo de ejecución de este último delito se alcanza en el momento exactamente posterior al de consumación del delito de falsedad documental. Por eso, iter criminis sin solución de continuidad. 


\section{BIBLIOGRAFÍA}

* ANTILOSEI, Francesco (1951): "Sull'essenza dei delitti contro la fede pubblica", Rivista italiana di Diritto penale, (Anno IV) pp. 625-642.

* BACIGALUPO, Enrique (2007): Falsedad documental, estafa y administración desleal, (Madrid, Marcial Pons) 245 pp.

* BINDING, Karl (1904): Lehrbuch des gemeinen deutschen Strafrechts, Besonderer Teil, t. II, $2^{\mathrm{a}}$ ed., (Leipzig, von Wilhelm Engelmann) 362 pp.

(1922): Die Normen und ibre Übertretung, tomo I, $4^{\text {a }}$ ed., (Leipzig, von Wilhelm Engelmann) 508 pp.

* BOLDOVA PASAMAR, Miguel (2000): Estudio del bien jurídico protegido en las falsedades documentales, (Granada) 165 pp.

* CLARO SOLAR, Luis (1939): Explicaciones de Derecho civil chileno y comparado, t. XII, De las obligaciones III, (Santiago, imprenta Nascimento) 822 pp.

* CORCOy BILDASOlO, Mirentxu / MIR PUIG, Santiago (2011): Comentarios al Código penal. Reforma LO 5/2010 (Valencia, Tirant lo Blanch) 1261 pp.

* COUSIÑO MAC IVER, Luis (1944): "La falsificación de instrumento privado", Revista de Ciencias Penales (2a época, t. VII) pp. 5-23 y pp. 99-131.

* DENCKER, Friedrich (2010): “Zur Täuschung im Rechtsverkehr”, en Joecks, Wolfgang y Ostendorf Heribert e.o. (eds.) Festschrift für Erich Samson, (Heidelberg, C.F. Müller) pp. 283-294.

* ERB, Völker (2014): \ 267, en Joecks, Wolfgang y Miebach, Klaus (eds.), Münchener Kommentar zum StGB, t. 5, 2a ed. (München, Beck) núm. marg. 1-230.

* FEUERBACH, Paul Johann Anselm (1847): Lebrbuch des gemeinen in Deutschland gültigen peinlichen Rechts, Mittermaier, Carl (ed.), $2^{a}$ impresión de 14 ${ }^{a}$ edición, (Giesen, Georg Friedrich Heyer's Verlag) 878 pp.

* FRANK, Reinhard (1908): Das Strafgesetzbuch für das Deutsche Reich nebst dem Einführungsgesetze, $6^{\mathrm{a}} / 7^{\mathrm{a}}$ ed. (Tübingen, Mohr), $671 \mathrm{pp}$.

* FREUND, Georg (2010): Urkundenstraftaten, 2a ed. (Heidelberg e.o., Springer) 179 pp.

* FRISTER, Helmut (2011): Strafrecht, Allgemeiner Teil, $5^{a}$ ed. (München, Beck) 479 pp.

* García CANTIZANO, María del Carmen (1997): Las falsedades documentales (en el Código penal de 1995) (Valencia, Tirant lo Blanch) $179 \mathrm{pp}$.

* Garrido MONTT, Mario (2008): Derecho penal, parte especial, t. IV (Santiago, Ed. Jurídica) 459 pp.

* GRISOLÍA, Francisco (1956): "Nota", Revista de Ciencias Penales (3" época, t. XV, mayodiciembre) pp. 95-98.

* HÄLSCHNER, Hugo (1868): System des preussischen Strafrechts, $2^{\mathrm{a}}$ parte (Bonn, Adolph Marcus) 565 pp.

(1887): Das gemeine deutsche Strafrecht, tomo II, $2^{\text {a }}$ sección (Bonn, von Adolph Marcus) 1091 pp.

* HEGEL, Georg Wilhelm Friedrich (1970): Grundlinien der Philosophie des Rechts oder Naturrecht und Staatswissenschaft im Grundrisse (Frankfurt a.M., Suhrkamp) 531 pp.

* HEINEMANN, Franz (1904): Das crimen falsi in der altitalienischen Doktrin (Berlin, Decker's Verlag) 36 pp.

* JAKOBS, Günther (1985 a): "Kriminalisierung im Vorfeld einer Rechtsgutsverletzung", Zeitschrift für die gesamte Strafrechtswissenschaft (vol. 97) pp. 751-785. (1985 b): "Die Aufgabe des strafrechtlichen Ehrenschutzes", en Vogler, Theo y Hermann, Joachim e.o. (eds.) Festschrift für Hans-Heinrich Jescheck, zum 70. Geburtstag, tomo I (Berlin, Duncker \& Humblot) pp. 627-643.

(1993): Strafrecht, Allgemeiner Teil, $2^{\mathrm{a}}$ ed. (Berlin / New York, de Gruyter) 944 pp. (2000): Urkundenfälschung (Köln e.o., Carl Heymanns) 106 pp. 
Rojas - Falsedad documental como delito contra el derecho a la verdad

(2007): "Bemerkungen zur Urkundenfälschung", en Hettinger, Michael y Hillenkamp, Thomas (eds.) Festschrift für Wiffried Küper (Heidelberg, C.F. Müller) pp. 225-236. (2008): "Rechtsentzug als Vermögensdelikt", en Sieber, Ulrich y Dannecker, Gerhard e.o. (eds.) Festschrift für Klaus Tiedemann zum 70. Geburtstag (Köln / München, Carl Heymanns), pp. 649-661.

* KAUfmanN, Armin (2006): Dogmática de los delitos de omisión (Madrid / Barcelona, Marcial Pons), 333 pp.

* KINDHÄUSER, Urs (1991): "Täuschung und Wahrheitsanspruch beim Betrug", Zeitschrift für die gesamte Strafrechtswissenschaft (vol. 103) pp. 399-424.

* KOHLRAUSCH, Eduard (1929): “Urkundenverbrechen”, en Stier-Somlo, Fritz y Elfter, Alexander (eds.) Handwörterbuch der Rechtswissenschaft (Berlin/Leipzig, de Gruyter) pp. 334-338.

* LAMPE, Ernst-Joachim (1957): Fälschung von Gesamturkunden und von zusammengesetzten Urkunden (Mainz, Dissertation) 70 pp.

* LENCKNER, Theodor (1967): "Zum Begriff der Täuschungsabsicht in \ 267 StGB", Neueuristische Wochenschrift, pp. 1890-1895.

* LISZT VON, Franz (1908): Lehrbuch des deutschen Strafrechts, 16 $/ 17^{\mathrm{a}}$ ed. (Berlin, Guttentag Verlagsbuchhandlung) 689 pp.

* LUHMANN, Niklas (1993): Das Recht der Gesellschaft (Frankfurt a.M., Suhrkamp) 598 pp.

* MALINVERNI, Alessandro (1958): Teoria del falso documentale (Milano, Giuffrè) 449 pp.

* MERKEL, Adolf (1867): Kriminalistische Abhandlungen, II. Lehre vom strafbaren Betrug (Leipzig, Breittopf und Härtel) 339 pp.

(1889): Lebrbuch des deutschen Strafrechts (Stuttgart, von Ferdinand Enke) 427 pp.

* MERKEL, Paul (1902): Die Urkunde im deutschen Strafrecht. Eine bistorische und kritischdogmatische Untersuchung (München, Beck'sche Verlagsbuchhandlung) 502 pp.

* MURMANN, Uwe (1999): Versuchsunrecht und Rücktritt (Heidelberg, C.F. Müller) 78 pp.

* PAWLIK, Michael (1999): Das unerlaubte Verbaltenm beim Betrug (Köln e.o., Carl Heymanns Verlag) 345 pp.

* PRECHTEL, Dietmar (2005): Urkundedelikte (Berlin, Berliner-Wissenschaft) 427 pp.

* PUPPE, Ingeborg (1972): Die Fälschung technischer Aufzeichnungen (Berlin, Duncker \& Humblot) $285 \mathrm{pp}$

(2009): "Die Wahrheitspflicht des Notars", en Kindhäuser, Urs (ed.) Strafrechtliche Aspekte notarieller Tätigkeit, (Baden-Baden, Nomos) pp. 8-16.

(2013): \267, en Kindhäuser, Urs, Neumann, Ulfrid y Paeffgen, Hans-Ulrich (eds.), Nomos Kommentar Strafgeseţ̧buch, $4^{a}$ ed. (Baden-Baden, Nomos) núm. marg. 1-121, \$ 271 núm. marg. 1-66, \ 348 núm. marg. 1-44.

* RHEINECK, Renate (1979): Fälschungsbegriff und Geistigkeitstheorie (Berlin, Duncker \& Humblot) 165 pp.

* ROJAS AGUIRRE, Luis Emilio (2012): "Historia dogmática de la falsedad documental", Revista de Derecho de la Pontificia Universidad Católica de Valparaíso (XXXIX, $2^{\circ}$ semestre) pp. 545-583.

(2013): "Dogmengeschichte der Urkundenfälschung", en Freund, Georg y Murmann, Uwe e.o. (eds.), Festschrift für Wolfgang Frisch zum 70. Geburtstag (Berlin, Duncker\&Humblot) pp. 925-947.

(2014 a): "Falsedad documental como delito de engaño", Revista Chilena de Derecho (vol. 41 N. 2, mayo-agosto) pp. 523-554.

(2014 b): "Deconstrucción del modelo dominante de comprensión de los delitos de falsedad documental", Politica criminal (vol. 9, N. 18, diciembre) pp. 477-520.

* ROXIN, Claus (2003): Strafrecht, Allgemeiner Teil, t. II (München, Beck) 899 pp.

* SAMSON, Erich (1968): Urkunde und Beweiszeichen (Baden-Baden, Nomos) 160 pp.

* STEINMETZ, Bernd (1991): Der Echtheitsbegriff im Tatbestand der Urkundenfälschung (d 267 StGB), (Berlin, Duncker \& Humblot) 273 pp. 
* VIllaCAMPA ESTIARTE, Carolina (1999): La falsedad documental: análisis juridico-penal (Barcelona, Cedecs) 906 pp.

* VORMBAUM, Moritz (2011): “Das Handeln 'zur Täuschung im Rechtsverkehr'. Zur Auslegung des \ 267 I StGB”, Goltdammer's Archiv für Strafrecht (vol. 158, N. 3) pp. $167-$ 182.

* WOHLERS, Wolfgang (2000): Deliktstypen des Präventionsstrafrechts - zur Dogmatik "moderner" Gefährdungsdelikte (Berlin, Duncker \& Humblot) 387 pp. 